\title{
19. Yüzyılda Osmanlı Saray Kadınlarının İnşa Ettirdiği Külliyelerin İstanbul Kent Dokusuna Katkılarının Değerlendirilmesi*
}

\author{
Complexes Built the Women of the Ottoman Court in the $19^{\text {th }}$ century, an Evaluation of \\ their Contribution to Istanbul's Urban Texture
}

\author{
Pınar Şahin $^{* \star}$ (D), F. Nalân Türkmen ${ }^{\star \star *}$ (D)
}

Öz

19. yüzyıl İstanbul'un kent dokusu açısından en büyük değişim yaşadığı asırdır. Reform hareketlerinin yoğunluk kazandığı bu dönemde devletin merkez teşkilatının batılı tarzda yeniden düzenlenmesi yanında şehircilik faaliyetleri açısından da birçok yeni uygulama yapılmıştır. 1855'ten sonra belediyelerin kurulması ile birlikte şehir planında önemli değişikliklerin yapılması, yerleşim alanlarının ve inşa faaliyetlerinin düzenlenmesi için ebniye nizannamelerinin hazırlanması bu dönemde meydana gelen önemli gelişmelerdir. Toplumsal hayatın her alanını etkileyen bu süreçte, Osmanlı saray kadınları baskın bir figür olarak karşımıza çıkmaktadır. Gerek şahsi birikimleri gerekse de devlet desteği ile inşa ve tamir ettirdikleri sosyal, askeri ve sivil yapılarla İstanbul şehir dokusunda kalıc izler bırakmışlardır. Modern şehircilik kavramının Osmanlı bayındırlık faaliyetlerine yeni bir yön verdiği 19. yüzyılda saray kadınlarının İstanbul’un silüetine damgasını vuran eserlere giderek artan bir ivme ile isimlerini verdikleri görülmektedir. Bu makalede saray kadınlarının inşa ettirdikleri Şah Sultan Külliyesi (1800), Nakşidil Vâlide Sultan Külliyesi (1818), Bezmiâlem Gurebâ-yı Müslimîn Hastanesi Külliyesi (1845), Bâlâ Süleyman Ağa Külliyesi (1863) ve Aksaray Vâlide Sultan Külliyesi (1871) ele alınmıştır. Araştırmada söz konusu yapılar konumları ve yapısal özellikleri ile dönem haritaları üzerinde incelenmiştir.

\section{Anahtar Kelimeler}

Osmanlı saray kadınları, İstanbul kent dokusu, Batılılaşma dönemi, Külliyeler, Modern şehircilik

\begin{abstract}
The $19^{\text {th }}$ century was the century in which the urban fabric of Istanbul underwent its biggest transformation. During this period when the reform movement gained momentum, the state carried out a Western-style restructuring and introduced many new city planning regulations. Among the important developments that took place in this period after municipalities were established in 1855 were significant changes to the city plan and the building regulations put in place to facilitate and coordinate the residential areas and constructions. This process affected all spheres of society and the women of the Ottoman court emerged as commanding figures. These women left their mark on Istanbul's urban fabric thanks to the constructions and repair of social, military, and secular architecture which they brought about either using personal
\end{abstract}

* Bu makale Marmara Üniversitesi Türkiyat Araştırmaları Enstitüsü Türk Sanatı Anabilim Dalı́nda Prof. Dr. F. Nalân TÜRKMEN danışmanlığında hazırlanan “XIX. Yüzyıl İstanbul Şehir Dokusunda Saray Kadınlarının Etkisi” başlıklı doktora tezinden üretilmiştir.

** Sorumlu Yazar: Pınar Şahin (Doktora Öğrencisi), Marmara Üniversitesi, Türkiyat Araşttrmaları Enstitüsü, Türk Sanat Anabilim Dalı, İstanbul, Türkiye. E-posta: pnr.sahin@hotmail.com ORCID: 0000-0002-4929-0104

*** F. Nalân Türkmen (Prof. Dr.) Marmara Üniversitesi, Fen-Edebiyat Fakültesi, Sanat Tarihi Bölümü, İstanbul, Türkiye. E-posta: nalanturkmen@gmail.com ORCID: 0000-0003-2033-3710

Atıf: Sahin, Pinar, Turkmen, F. Nalan, “19. Yüzyılda Osmanlı Saray Kadınlarının İnşa Ettirdiği Külliyelerin İstanbul Kent Dokusuna Katkılarının Değerlendirilmesi." Art-Sanat, 17(2022): 419-450. https://doi.org/10.26650/artsanat.2022.17.963954 
savings or state funding. Modern city planning gave Ottoman construction projects a new direction, it is evident that the numbers of buildings named after and funded by the women of the Ottoman court in the $19^{\text {th }}$ century gathered momentum, and these structures have left their mark on Istanbul's skyline. This article deals with the edifices built by ladies of the Ottoman court, namely the Şah Sultan Complex (1800), the Nakşidil Valide Sultan Complex (1818), the Bezmiâlem Gurebâ Müslimîn Hospital Complex (1845), the Bâlâ Süleyman Ağa Complex (1863) and the Aksaray Valide Sultan Complex (1871). These buildings have been studiedtheir location and structural features and they were examined on contemporary maps.

Keywords

Ottoman Court women, Istanbul's urban fabric, the Westernisation period, Complexes, Modern town planning

\section{Extended Summary}

In the literature of art history buildings erected by the sultans' consorts, mothers or daughters are studied as a concept known as Woman Builders. Recent research has shown that women builders, or architecture under female patronage, occupy a special place in the history of architecture and that women played an active role as builders in Turkish Islamic architecture since the Anatolian Seljuk period. In the $16^{\text {th }}$ century, the golden age of Ottoman architecture, the buildings built by the sultanas became more of a standardised court tradition. Trusts established by the women of the Ottoman court - the sultans' consorts, mothers, and daughters - were involved in large building projects, they even influenced the imperial architects. There are many $16^{\text {th }}$ and $17^{\text {th }}$ century mosques, madrasah, Turkish baths, primary schools, hospitals, darülkurra (a place for learning to read the Quran) and soup kitchens built upon the sultanas' initiative.

The Ottoman sultanas erected many mosque complexes in the classic age of the Ottoman Empire and in the period that followed. Usually built in the name of the sultans' mothers, they would leave their mark on the districts where they were built. The most prominent feature of the buildings from this period was their size and splendour, which had to eclipse all the others. The best-known examples are the Haseki Hürrem Sultan Complex (1551) in Avratpazarı, the Mihrimah Sultan Complexes in Üsküdar (1547) and Edirnekap1 (1563-1571), the Atik Vâlide Complex in Üsküdar (1570-1579) and the Yeni Vâlide Complex in Eminönü (1597-1663).

The $19^{\text {th }}$ century saw the commencement of modernisation in the Ottoman community and the state organization. The modernization efforts that began during the reign of Selim III (1789-1808) and continued with Mahmud II (1808-1839), acquired a greater dimension with the Imperial Edict of Reorganisation (1839) proclaimed by Abdülmecid (1839-1861). The radical changes brought about by the edict led to great strides being made by the Ottoman State and the community towards alignment with the West. The change began on a political platform and the effect soon began to appear everywhere. From the aspect of architecture, new types of buildings emerged because social, political and economic requirements. The important developments 
in this period following the establishments of the municipalities in 1855 were the building regulations put in place to facilitate important changes to the city plan and the coordination of residential areas and constructions.

When architecture came under Western influence in the $19^{\text {th }}$ century he concept of modern city planning steered Ottoman construction projects in a new direction. The growing impetus by which the women of the Ottoman court gave their names to buildings that had an impact on Istanbul's silhouette is evident. During this period a not insubstantial number of buildings were constructed upon the initiatives of the sultanas. The women's architectural ambitions focused mainly on mosques, madrasahs, primary schools, Turkish baths, soup kitchens and fountains. Five complexes were built that played an important role in the transformation of the city. The Şah Sultan Complex (1800), the Nakşidil Valide Sultan Complex (1818), the Bezmiâlem Gurebâ-y1 Müslimîn Hospital Complex (1845), the Bâlâ Süleyman Ağa Complex (1863) and the Aksaray Valide Sultan Complex (1871) were consequential building projects that left their mark on the period.

The Şah Sultan Complex and the Nakşidil Sultan Complex built by women of the Ottoman court in the $19^{\text {th }}$ century, were built in Istanbul's religious centres. The Şah Sultan Complex, which consists of a tomb, a primary school, a public fountain, and a drinking fountain, is located at the entrance to the district of Eyüpsultan next to the old road leading from Edirnekap1 to Eyüpsultan. The Nakşidil Sultan Complex, containing a tomb, primary school, public fountain, and soup kitchen, is located in the enclosed area of the first Selâtin Mosque and Complex which forms Fatih's core.

The other notable complexes built in the $19^{\text {th }}$ century-the Gurebâ-y1 Müslimîn Hospital Complex, the Bâlâ Süleyman Ağa Complex and the Aksaray Vâlide Complex-were built where the city's social infrastructure was inadequate, in underdeveloped areas. Large structures containing entities such as mosques, primary schools and fountains which fulfilled the everyday needs of the population, became some of the main elements of city planning. Over time the districts around the complexes have become more populated and today they have turned into busy urban hubs. The Gurebâ-y1 Müslimîn Hospital Complex in Yenibahçe built by Bezmiâlem Valide Sultan, the Bâlâ Süleyman Ağa Complex in Silivrikapı built by Âdile Sultan and Perstû Kadınefendi and the Vâlide Complex built by Pertevniyal Vâlide Sultan have contributed significantly to the development of Aksaray, where it was built.

The Gurebâ-yı Müslimîn Hospital Complex was built by Bezmiâlem Valide Sultan, and it is significant because it was one of the largest hospitals of the century. Yenibahçe Çayırı was the chosen site for the edifice that stood as a new model for modern healthcare establishments. The important point about this area is that it was far from the city, in a spacious, green environment well suited for treating the sick. After the 
Proclamation of the Republic, the area continued to be one of Istanbul's important health centres. Besides the Vakıf Gureba Hospital, other medical facilities such as Istanbul University's Faculty of Medicine, the Red Crescent Blood Donation Centre, and the Private Çapa Hospital also accumulated in that area.

Apart from the Gurebâ-yı Müslimîn Hospital Complex, another important complex, the Bâlâ Süleyman Ağa Complex was built by Sazkâr Kalfa, Adile Sultan ve Perestû Kadın Efendi to meet people's basic needs for worship, education and water. The Bâlâ Süleyman Ağa Complex is also interesting because of its contribution to the city fabric. The roads running between the buildings provide circulation and form the district's network of streets.

The complex built by Pertevniyal Vâlide Sultan in place of the Kâtip Mosque in Aksaray is the most comprehensive group of structures built by a woman of the imperial court in the $19^{\text {th }}$ century. The Valide Complex in Aksaray is in a district where modern city planning was first implemented. It was the scene of urban planning not witnessed in Ottoman history until the $19^{\text {th }}$ century. After a great fire in the district back in 1854 , the Italian engineer Luigi Storari was commissioned to carry out the reconstructions and for the first time, Istanbul's city plan had a parallel street system and a Western-style square. The Pertevniyal Vâlide Sultan Complex's Mosque, tomb and public fountain were built on the corners of this square in Aksaray. Locations and structural features, contemporary maps, and the impact on the city fabric of $19^{\text {th }}$ century Istanbul have been analysed for this study on the social complexes built by the women of the Ottoman court. 


\section{Giriş}

Hanım sultanlar Türk-İslam mimarisinde büyük imar faaliyetlerinde bânî olarak yer almışlardır. İslam yolunda hizmet etmek ve halk tabanında saygınlıklarını arttırmak için özellikle saray içindeki güç sahibi hanım sultanlar yaptırdıkları külliye kuruluşlarında cami, medrese, dârülkurra gibi dini kurumlarının yanı sıra imaret-aşevi ve darüşşifa gibi hayır yapılarına da yer vermişlerdir.

Türk Sanat Tarihi üzerine yapılan son araştırmalar kadınların Selçuklular'dan itibaren Anadolu-İslâm mimarlığında aktif olduklarını ve kadın bâniliğin kendine has bir alan teşkil ettiği sonucunu ortaya koymaktadır. Bilhassa Osmanlı son döneminde padişahların eşleri, valide ve kızlarının oluşturduğu hanım sultan ekolü sistemli bir saray geleneği hâline gelmiştir.

Osmanlı saray kadınları, mimariyi kendilerini temsil etmenin ve toplumda görünürlük edinmenin aracı olarak erken dönemlerden itibaren kullanmışlardır. Gerek hanedana mensup kadınların gerek Osmanlı toplumunun farklı statülerine sahip varlıklı kadınlarının toplumsal ya da siyasi güçleri hayırseverliklerinin en açık göstergesi olan inşa faaliyetlerinde görülmektedir ${ }^{1}$. Osmanlı kadınlarının konumlarını ve dindarlıklarını halka göstermelerinin başlıca yolu mimariyi himaye etmeleri olmuştur. ${ }^{2}$ Bilhassa Mimar Sinan döneminde saray kadınlarının çok sayıda hayır eseri ve cami yaptırmalarını önemli bir güç göstergesi olarak vurgulayan Akçıl, kadınların inşa faaliyetlerini toplum içinde arka planda kalan konumlarının aksine, kamusal alanda artan nüfuzlarının bir göstergesi olarak değerlendirmiştir³.

Saray kadınlarının mimari etkinlikleri 16-18. yüzyıllarda Üsküdar'da yoğunlaşmıştır. Söz konusu bölgedeki büyük programlı yapıların birçoğu valide sultanlar başta olmak üzere hanedanın kadın mensupları için inşa ettirilmiştir. Gülfem Hatun, Mihrimah Sultan, Nurbanu Sultan, Kösem Sultan, Gülnuş Sultan, Mihrişah Sultan, Şermi Rabia Sultan'ın adına yaptırılan ve Üsküdar'ın farklı noktalarına konumlandırılan külliyeler bu alandaki en kapsamlı inşa faaliyetleridir. Saray kadınlarının yaptırdıkları binaların anıtsallıkları ve geniş organizasyonlarının yanı sıra kent içindeki konumları itibariyle de birer kentsel imge olduklarını ifade eden Kalafat bu özelliğinden dolayı Üsküdar'ı harem kadınları için bir "prestij sahası” olarak adlandırmıştır".

Hanım sultanların imparatorluğun en parlak dönemi olan 16. yüzyılda inşa ettirdikleri külliyeler büyüklük ve ihtişamlarıyla öne çıkmaktadır. Kadın bâniler kurdukları vakıflarla desteklenen yapıların inşa sürecinde, hassa mimarlarını yönlendirmişler

1 Ayşe Çıkla Bölükbaşı, "Erken Osmanlı Devleti’nde Kadınların Mimari Alandaki Hamiliği (1299-1512)", Sanat Tarihi Ylllı̆̆ 19 (2007), 82.

2 Lucienne Thys-Şenocak, Hadice Turan Sultan Osmanlı İmparatorluğunda Kadın Bâniler, çev. Ayla Ortaç (İstanbul: Kitap Yayınevi, 2009), 80.

3 N. Çiçek Akçıl Harmankaya, Mimar Sinan Camilerinde Sembolizm, (İstanbul: Kitabevi Yayınları, 2018), 42.

4 Murat Kalafat, "Üsküdar: Harem Kadınlarının Prestij Sahası”, Art- Sanat 14 (2020), 194-204. 
ve yapım faaliyetlerinin kesintisiz devamı hususunda aktif rol oynamışlardır. Bu dönemde kadınların inşa ettirdikleri yapılar ilk kez imparatorluğun başkentinde yer almaya başlamıştır ${ }^{5}$. Kanûni Sultan Süleyman döneminde Osmanlı Devleti’nin ulaştığı zenginlik hanım sultanların vakıflarına da yansımıştır. Bu devirde hanım sultanların yaptırdığı büyük ölçekli külliyeler, günümüzde de İstanbul'un silüetine damgasını vuran simge kuruluşlardır.

Hürrem Sultan'ın İstanbul'un Fatih semtinde, inşa ettirdiği külliyesi, Mimar Sinan'ın Hassa Mimarbaşı olarak yaptığı ilk büyük ölçekli hanım sultan eseridir. Avratpazarı olarak bilinen yerde inşa edilen külliye; cami, medrese, imaret, darüşşifa ve sıbyan mektebinden oluşmaktadır. Yapılar dönemin ihtiyaçlarına cevap verdikleri gibi modern devletin kurulmasından sonra da İstanbul'un önemli bir sağlık merkezi olma işlevini sürdürmüştür. Ayrıca Sinan'ın mekân düzenleme başarısını en iyi yansıtan örneklerden bir olan Haseki Darüşşifası Osmanlı'nın ilk kadın hastanesi olması açısından önemlidir. ${ }^{6}$

Kanûnî ve Hürrem Sultan'ın kızı Mihrimah Sultan da annesi gibi oldukça önemli bir vakıf kurucusudur. Mimar Sinan'ın imzasını taşıyan Üsküdar Mihrimah Sultan Cami (1547) ve Edirnekapı Mihrimah Sultan Cami (1563-1571) konumları itibariyle şehrin kara ve deniz silüetlerinde öne çıkan yapılardır. Üsküdar Mihrimah Sultan Külliyesi cami, medrese, mektep, imaret ve han gibi değişik birimlerden oluşan sosyal fonksiyonlu binalarla semtin artan günlük ihtiyaçlarına cevap vermiştir ${ }^{7}$. Erzen'e göre külliyenin en önemli özelliği kent planlamasının bir parçası olarak deniz ticaretine olan katkısıdır ${ }^{8}$. Mihrimah Sultan'ın inşa ettirdiği diğer külliye, şehrin batı ucuna padişahın sefer dönüşünde şehre giriş için kullandığı Edirnekapısı yakınında yer almaktadır. Sinan'ın diğer külliyelerinde de olduğu gibi yapılar arazi şartlarına uygun yerleştirilmiştir. Bates, külliyenin camisinin İstanbul'daki en aydınlık iç mekâna sahip yap1 olduğunu belirtmektedir9.

16. yüzyılda adından pek söz edilmeyen kadın bânilerden biri Kanuni Sultan Süleyman'ın hasekilerinden Gülfem Hatun'dur. Gülfem Hatun'un 1542 yılında Üsküdar'da yaptırdığ 1 cami, kervansaray, mektep ve imaretten oluşan külliyesi günümüze ulaşamamıştır. Sultanın vakfına ait binalardan sadece Gülfem Hatun Mahallesi'nde bulunan ve 1869 y1lından sonra yenilenen cami mevcuttur ${ }^{10}$.

5 Leslie P. Pierce, Harem-i Hümayûn Osmanlı İmparatorluğunda Hükümdarlık ve Kadınlar, çev. Ayșe Berktay, (İstanbul: Tarih Vakf1 Yurt Yayınları, 1996), 264.

6 Tülay Akkan, “Mimar Sinan’ın Saraylı Kadınlar İçin Yapmış Olduğu Eserler ve Bu Eserlerin Mimari Özellikleri”, (Yüksek Lisans tezi, Mimar Sinan Güzel Sanatlar Üniversitesi 2009), 120-121.

7 Mahmut Ak, "Vakıf Kurucusu Bir Hanım: Mihrimah Sultan," Vakıflar Dergisi: Vakıf Medeniyeti Yllı Özel Saylsl, (2006), 84-87.

8 Jale N. Erzen, Mimar Sinan Estetik Bir Analiz (Ankara: Şevki Vanlı Mimarlık Vakfı Yayınları,1996), 19.

9 Ülkü Bates, "Women as Patron of Architecture in Turkey", Women in Muslim World, ed. Lois Back ve Nikki Keddie (Cambridge: Harvard University Press, 1978), 254.

10 Tahsin Özcan, "Vakıf Şehidi Bir Saraylı: Gülfem Hatun”, Vakıflar Dergisi: Vakıf Medeniyeti Yllı Özel Saylsl, (2006), 97-98. 
Üsküdar'da III. Murad'ın annesi ve II. Selim'in eşi Nurbânu Sultan için Mimar Sinan tarafindan inşa edilen Atik Valide Külliyesi (1570-1579) bu tarihe kadar İstanbul'da kadın bânilerin yaptırdığı en kapsamlı külliyedir. Cami, imaret, kervansaray, darüşşifa, dârulkurra, hamam ve tekke yapıları topoğrafyaya uygun yerleştirilmiştir ${ }^{11}$.

Kadın bânilerin inşa faaliyetleri 17. yüzyılda da kesintisiz devam etmiştir. Üsküdar'da inşa edilen hanım sultan yapılarından biri de Sultan I. Murad'ın eşi, IV. Murad ve Sultan İbrahim'in annesi Kösem Mahpeyker Valide Sultan'a ait olan Çini Camii ve Külliyesi'dir. Cami, medrese, sıbyan mektebi, sebil, çeşme ve çifte hamamdan müteşekkil külliyenin inşa tarihi 1640'tır. XVII. yüzyıl külliye mimarisinin genel özelliklerini yansıtan yapı araziye uygun bir şekilde dağınık olarak yerleştirilmiştir. Külliyenin camisi Kütahya çinileriyle kaplı süsleme programı ile ünlüdür ${ }^{12}$.

İnşası 1597'de III. Murad'ın eşi Safiye Sultan tarafindan başlatılan, 1663'te IV. Mehmed'in annesi Hatice Turhan Valide Sultan tarafından tamamlanan Eminönü Yeni Camii dönemin önemli yapılarındandır. Doldurma bir zemin üzerine yerleştirilen Yeni Cami, dört yönden yarım kubbe ile genişletilen merkezi kubbeli plan şeması ile İstanbul'un en büyük ölçekli hanım sultan camisidir ${ }^{13}$.

Sultan IV. Mehmed'in eşi aynı zamanda II. Mustafa ve III. Ahmed'in annesi Gülnuş Emeteullah Valide Sultan'ın yaptırdığı Yeni Valide Külliyesi (1708-1710) ile Üsküdar'da hanım sultanların yapım faaliyetleri devam etmiştir. Bu külliye; cami, türbe, sıbyan mektebi, çeşme, arasta, imarethane ve muvakkithaneden oluşmaktadır. Üsküdar Yeni Valide Camii, Lâle Devri'nin mimaride henüz etkisini göstermediği bir dönemde klasik dönem özelliklerinin genel hatları ile sürdürüldüğü bir uygulamadır' ${ }^{14}$.

Sultan I. Abdülhamid'in annesi Şermi Rabia Sultan için inşa edilen Beylerbeyi Camii ve Külliyesi (1778) İstanbul'un Anadolu yakasına aynı isimle anılan semtte inşa edilmiştir. Cami, hamam, sıbyan mektebi, muvakkithane ve iki çeşmeden müteşekkil yapılar topluluğu Mimar Tahir Ağa tarafından tasarlanmıştır. Beylerbeyi ya da Hamid-i Evvel Valide Cami barok üslubunda bir boğaz camisidir ${ }^{15}$.

Türk-İslâm mimarisinde hanım sultanların hayır eseri yaptırma eylemleri Osmanlı’nın son döneminde de devam etmiştir. 19. yüzyılda öne çıkan saray kadınları Bezmiâlem Valide Sultan, (1807? -1853) Pertevniyal Valide Sultan (1810?-1884), Âdile Sultan (1826-1899), Nakşidil Valide Sultan (1766-1817) ve Şah Sultan (1761-1801)'dır.

11 Akkan, "Mimar Sinan'in Saraylı Kadınlar İçin Yapmış Olduğu Eserler ve Bu Eserlerin Mimari Özellikleri”, 122.

12 Doğan Kuban, Osmanlı Mimarisi, (İstanbul: Yem Yayınları, 2007), 384.

13 Tolga Bozkurt, "Osmanlı Mimarisinde Hanım Sultan Camileri”, Din ve Hayat 48 (2013), 50.

14 Kuban, Osmanlı Mimarisi, 384.

15 Selçuk Mülayim, "Beylerbeyi Camii ve Külliyesi, TDV İslâm Ansiklopedisi, c. 6 (İstanbul: Türkiye Diyanet Vakfi, 1992), 75. 


\section{Yüzyılda Osmanlı Saray Kadınlarının İnşa Ettirdiği Külliyeler}

19. yüzyıl İstanbul'un kent dokusu açıssından en büyük değişimin yaşandığı dönemdir. Devletin merkez teşkilatında başlayan reform hareketleri şehircilik çalışmalarını da etkilemiştir. Batılılaşma süreci ile birlikte imar faaliyetleri artmış, değişen hayat tarzı yeni yapı tiplerinin ortaya çıkmasına sebep olmuştur. Bu süreçte İstanbul'un yapılanmasında hanedanın erkek üyeleri kadar kadın üyelerinin de etkin rol oynadığı bilinmektedir. Batılılaşma döneminde gereksinim duyulan birçok yapının inşası Osmanlı saray kadınlarının himayesinde gerçekleştirilmiştir.

19. yüzyılda saray kadınlarının inşa ettirdiği ilk külliye 1800 tarihli Şah Sultan Külliyesi'dir. Türbe, sıbyan mektebi, sebil, çeşme ve hazireden oluşan yapılar topluluğu Haliç kıyısında Edirnekapı'dan Eyüpsultan merkezine uzanan eski tarihi yolun (Cülûs Yolu) kenarında ve semte girişte yer alır. Defterdar Caddesi olarak anılan bu istikametin adı günümüzde Feshane Caddesi'dir.

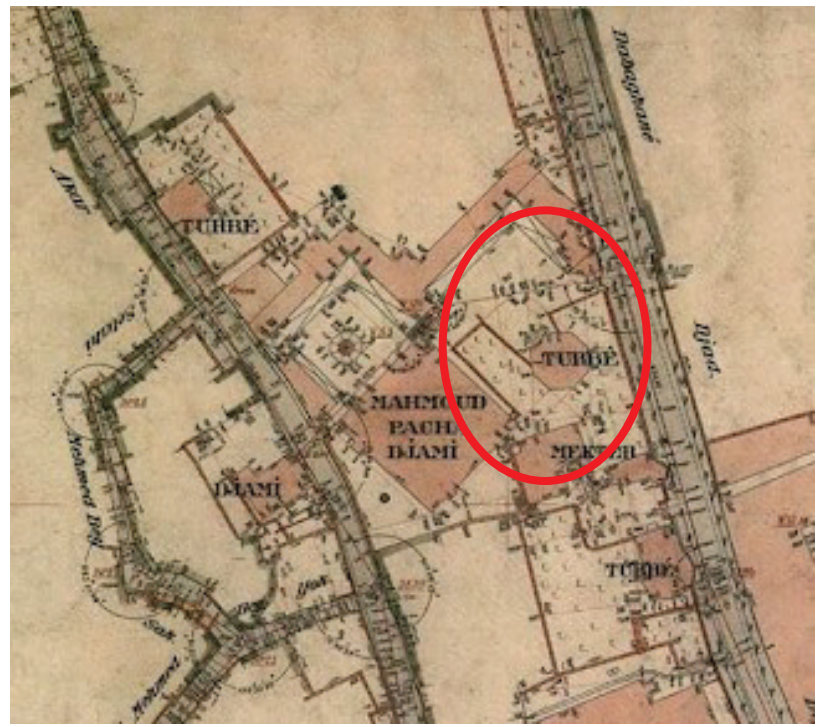

G. 1: Şah Sultan Külliyesi.

(Alman Mavileri :1913-1914 I. Dünya Savaş1 Öncesi İstanbul Haritaları, L13/3)

Yabancı seyyahların 'kutsal şehir' ${ }^{16}$ olarak adlandırdıkları Eyüpsultan tarih boyunca Osmanlı padişahlarının önem verdikleri bir semttir. III. Selim döneminde Eyüpsultan önemli inşa faaliyetlerine sahne olmuştur. 1766 depreminde büyük zarar gören ve tamir edilemez duruma gelen Eyüpsultan Camii III. Selim tarafından yeniden inşa edilmiştir. Fatih döneminde yaptırılan cami daha geniş inşa edilip, muvakkithane, şerbethane, abdest muslukları, hünkâr mahfiline giden kapı ve geçit eklenerek büyük

16 Edmondo De Amics, İstanbul (Constantinopoli), çev. Sevinç Tezcan Yanar (İstanbul: Pegasus Yayınları, 2009), 334. 
programlı bir yap1 grubu oluşturulmuştur ${ }^{17}$. III. Selim, banisi olduğu yeni caminin açılışını 24 Ekim 1800 tarihinde Cuma namazını kıldıktan sonra yapmıştır ${ }^{18}$.

18. yüzyıl Sultan III. Selim döneminin Eyüpsultan'daki eserlerinden biri de 1792-1796 yılları arasında annesi Mihrişah Vâlide Sultan adına Cülûs Yolu üzerine yapılan imaret sıbyan, mektebi, sebil ve türbeden oluşan Mihrişah Vâlide Sultan Külliyesi'dir. Yine annesi adına inşa edilen Halıcıoğlu'ndaki Mihrişah Valide Sultan Camii, Hasköy'de Lağımcılar ve Humbaracılar Kışlaları ile Mühendis Hane-i Berri Hümayûn Haliç’in iki yakasını süsleyen önemli yapılardır.

Kardeşleri Hatice Sultan, Beyhan Sultan ve Şah Sultan'ın sahilsaraylarının Eyüpsultan'da olması, annesi ve üç kız kardeşinin türbelerinin buraya inşa edilmesi, kız kardeşleri ve annesine olan düşkünlüğü ile bilenen padişahın Eyüpsultan ile arasındaki bağları kuvvetlendiren temel unsurlardandır. Bu sebeple Eyüpsultan III. Selim için sadece kutsal bir mekân olmasının yanı sıra en sevdiklerinin hatırasını ve varlıklarını sürdürdükleri bir semt olarak da anlam kazanmıştır.

19. yüzyılda III. Selim döneminin Eyüpsultan'daki en büyük hayır eseri kız kardeşi Şah Sultan'ın inşa ettirdiği külliyedir. Külliye binalarına yer açmak için harap durumdaki Nâfiz Feyzullah Efendizâde Hamid Molla Efendi Konağı ve bitişiğinde yer alan İskender Bey Mektebi kaldırılmıştır ${ }^{19}$. Şah Sultan, İstanbul'un bu uhrevî semtindeki külliyeyi 1799 yılında vefat eden annesi Mihrişah Kadın'ın ruhu için yaptırmıştır. ${ }^{20}$. 1844 yılında Eyüpsultan'a gelen gezgin Charles White külliye hakkında şu bilgileri vermiştir: Yeni kurulan fes fabrikasından sonra ilk türbe Şah Sultan'a aittir. Esma Sultan sarayının hemen karşısında yer alan bir vakıf okulu ve çeşmesi bulunan türbe, annesi, kocası ve Şah Sultan'ın mezarlarını içerir ${ }^{21}$.

Şah Sultan Külliyesi (1800) mahalle dokusu içinde yer alan küçük ölçekli bir hayır külliyesidir. Yerleşim düzenine bakıldığında yapıların topografyaya uygun olarak

17 Sarraf Hovhannesyan Selim'in camiyi daha geniş olarak yeniden inşa edip dış avluyu da büyüterek ihya ettiğinden bahseder. Bk. S. Sarraf Hovhannesyan, Payitaht İstanbul'un Tarihçesi, çev. Elomon Hançer, haz. Ayşen Anadol (İstanbul: Tarih Vakfı Yurt Yayınları, 1996), 33.

18 Hüseyin Ayvansarayî, Ali Satı' Efendi ve Süleymân Besîm Efendi, Hadikatü'l- Cevâm 'i: (İstanbul Camileri ve Diğer Dini-Sivil Mimari Yapılar) haz. A. Nezih Galitekin (Ankara: İşaret Yayınları, 2001) 338; Ahmed Efendi, Ruznâme, haz. V. Sema Arıkan (Ankara: Türk Tarih Kurumu Yayınları, 1993), 339.

19 M. Nermi Haskan, Eyüp Tarihi (İstanbul: Türkiye Turing Turizm İşletmeciliği Yayınları 1993), 1:266-267; Sevgi Parlak, "Şah Sultan Külliyesi”, TDV İslâm Ansiklopedisi, c. 30 (İstanbul: Türkiye Diyanet Vakfi, 2010), 258.

20 III. Mustafa’nın birinci ve üçünü kadınlarının adı Mihrişah’tır. Birçok kaynakta bu iki kadının ismi karıştırılmaktadır. Birinci kadın Mihrişah (ö.1805) III. Selim'in annesi olup valide sultan payesi almıştır. İkinci kadın olan Mihrişah (ö.1799) Şah Sultan'ın annesidir. Şah Sultan Külliyesi'nin giriş kapısı üzerindeki kitabede Mihrişah Kadın'ın (ö.1799) III. Mustafa'nın ikinci kadını olduğu açıkça belirtilmiştir: Hakkın Önkal, “Eyüp Mihrişah ve Şah Sultan Türbelerinin Kitabeleri Işı̆̆ında Mihrişah Kadın Meseleleri” V. Tarihi, Sanatı ve Kültürüyle Eyüpsultan Sempozyumu, (İstanbul: Eyüp Belediyesi Yayınları, 2002), 124.

21 Charles White, Tree Years in Constantinople; or Domestic Manners the Turks in 1844 (London: Henry Colburn Publiser, 1846), 3: 344. 
konumlandırıldığı görülmektedir. Kare bir avlunun doğusuna yapılar türbe ve mektep-sebil şeklinde gruplandırılmıştır. Avlu kapısı ana caddeye açılan külliyenin batı kısminda haziresi yer alır.

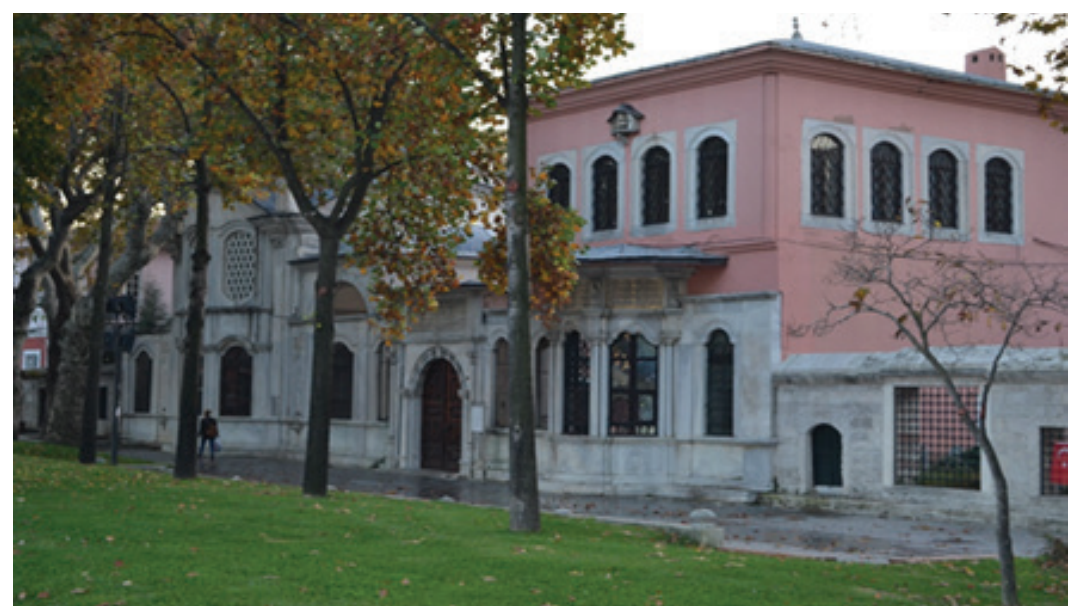

G. 2: Şah Sultan Külliyesi genel görünüşü. (Pınar Şahin Arşivi, 2018)

Şah Sultan Külliyesi (1800) şehircilik açısından değerlendirildiğinde cadde-sokak ile kurduğu ilişki oldukça dikkat çekicidir. Feshane Caddesi boyunca uzanan yapıların cephesi, hemen yanında bulunan 1580 tarihli Zal Mahmud Paşa Camii'nin ${ }^{22}$ masif kütlesi ile güçlü bir kontrast yaratmaktadır. Freely, Haliç kıyısına ve caminin kuzeyine inşa edilen yapıdan 'büyüleyici', 'karmaşık' ve 'barok külliyelerin en güzeli' olarak bahsetmiştir ${ }^{23}$.

Külliye, âdeta sokağın görüntüsünü tamamlayan bir tasarıma sahiptir. Şah Sultan yapılar topluluğunun doğu cephesi cadde üzerinde yer almaktadır. Külliye avlu kapısının güneyinde türbe, kuzeyinde ise sebil-i küttap vardır. Kuban'a göre bu uygulama 'alçakgönüllü' fakat 'etkileyici' bir kompozisyondur ${ }^{24}$. Türbe içte daire planlı olup dıştan kare planlı bir forma sahiptir. Köşelerde zengin profillerle biten plastırlar, üzerine yükselen kuleciklerle vurgulanmıştır. Kubbesi doğrudan duvarlara oturan türbenin eğri yüzeylerinin kornişleri köşe plastırları arasında yine ağır silmelerle belirginleştirilmiştir. Cepheye bitişik olarak inşa edilen barok türbe, yuvarlatılmış yüzeyi ve kare formuyla dış cephede iç içe geçmiş öğelerle oluşturulan süslemeleri ile cadde dokusuna dekoratif bir etki katmaktadır. Kuban'a göre Şah Sultan Türbesi’nin İstanbul mimarisindeki özel yeri ikinci kat pencerelerinin eliptik formundan gelmektedir ${ }^{25}$.

22 Semavi Eyice, “Eyüp'de Zal Mahmud Paşa Camii”, V. Tarihi ve Kültürü ve Sanatıyla Eyüpsultan Sempozyити, (İstanbul: Eyüp Belediyesi Yayınları, 2002), 13.

23 John Freely, A History of Ottoman Architecture (Boston: Wit Press Publishes, 2011), 394.

24 Kuban, Osmanlı Mimarisi, 548.

25 Kuban, Osmanlı Mimarisi, 548. 


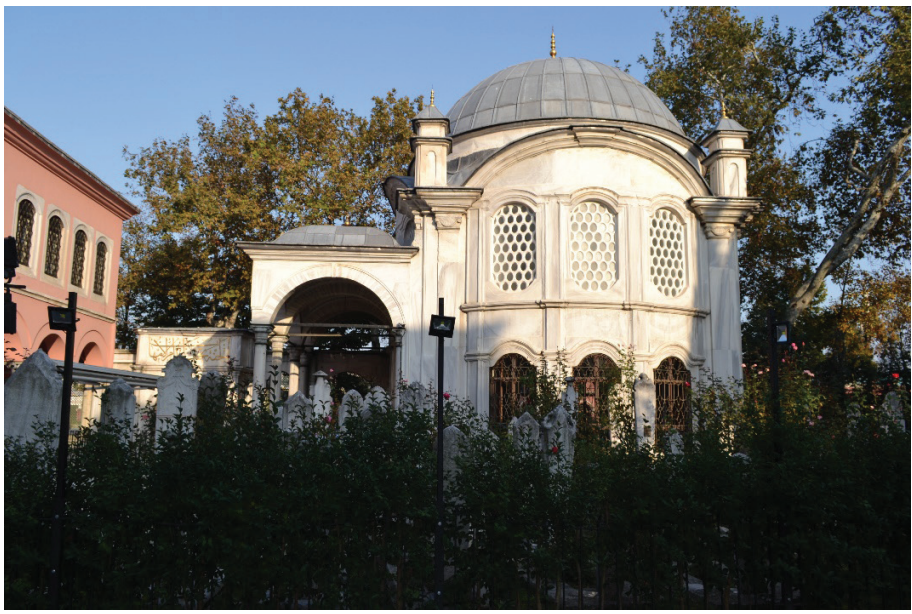

G. 3: Şah Sultan Türbesi (Pınar Şahin Arşivi, 2018)

Barok ve rokoko karışımı sebilin üzerine ampir üslubunda bir sıbyan mektebi inşa edilmiştir. Şah Sultan mektep ve sebili Kahire'de birçok örneği bulunan ve 16. yüzyılda İstanbul'da da görülen sebil-i küttap kompozisyonunun Eyüpsultan'daki tek örneğidir ${ }^{26}$. Sebilin oldukça zengin tezyinatı, türbeyi oluşturan dairesel formların gövdesinde ve saçağında tekrar edilmesi cephedeki etkisini arttırmıştır. Bununla birlikte gövde ve saçağı ile cadde içine taşkın biçimde ele alınması yoldan geçenlerin bu yap1 ile zorunlu ilişki kurmasına sebep olmuştur. Avlu duvarından dışarı taşan sebil cephede perspektif etkisi yaratmıştır. Dairesel formu ile avlu cephesini yumuşatan yapı, caddenin ifade kazanmasına yardımcı olmaktadır.

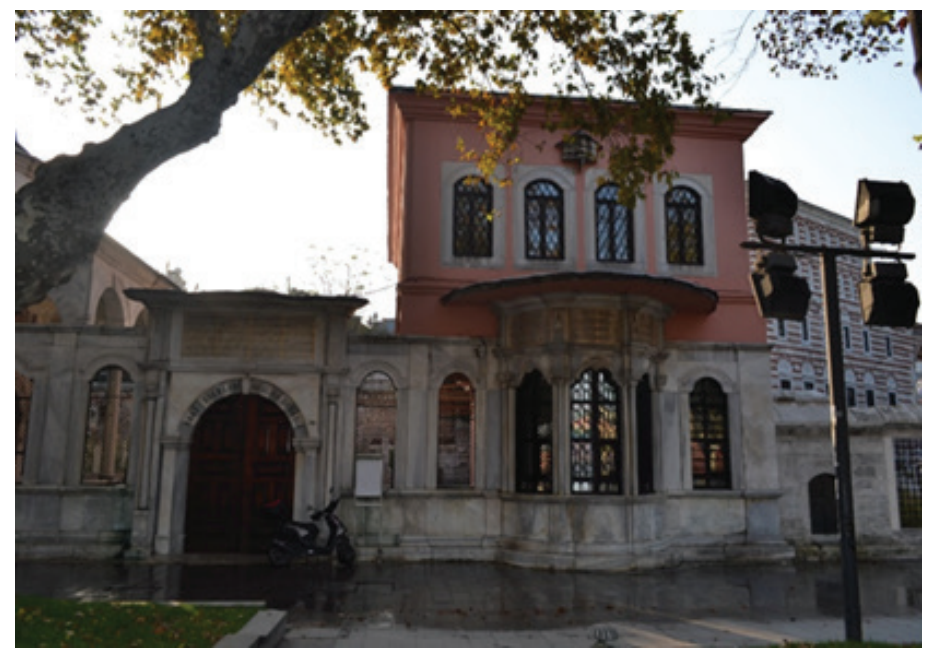

G. 4: Şah Sultan Sebili ve Sıbyan Mektebi. (Pınar Şahin Arşivi, 2018)

26 Zeynep Ahunbay, “Eyüp’teki Osmanlı Eğitim Yapıları ve Korunmalarıyla İlgili Öneriler”, IV. Tarihi ve Kültürü ve Sanattyla Eyüpsultan Sетроzyити (İstanbul: Eyüp Belediyesi Yayınları, 2000), 136. 
Şah Sultan Külliyesi'nin cephe düzeninde hayır vurgusu yoğun biçimde görülmektedir. Ana cadde üzerindeki ön cephede su mimarisinin fazla kullanılması ilgi çekicidir. Sokağa yarım daire biçiminde açılan sebil yoldan geçenlerinin su ihtiyacı$\mathrm{n}$ karşılamak için hizmete sunulmuştur. Sebilden başka türbenin iki yanına eklenen akant yapraklı küçük çeşmelerin dış cephede olması sokaktan geçenlerin suya ulaş1mında gözetilen hassasiyetin göstergesidir. Sebilin üzerine eğitim çağındaki çocuklar için inşa edilen mektep ve cephesindeki üç boyutlu kuş evi III. Selim'in kardeşi Şah Sultan'ın hayırseverliğinin ve cömertliğinin cephedeki yansımasıdır.

İkinci yapı grubu ise Nakşidil Valide Sultan Külliyesi'dir (1818). Fatih Camii’nin kıble yönüne inşa edilmiş türbe, sebil, çeşme, sıbyan mektebi ve imarethaneden oluşmaktadır. Külliyenin kuruluşu II. Mahmud'un hayırsever annesi Nakşidil Sultan'ın inşa ettirdiği sıbyan mektebi ile başlamıştır. Nakşidil Sultan'ın 1817 yılında vefatı ile birlikte arazi üzerine yapılacak diğer binaların mülkiyeti miras yoluyla oğluna geçmiş ${ }^{27}$ ve sıbyan mektebinin bulunduğu araziye annesinin ruhu için türbe, sebil, çeşme ve imarethane yaptırılarak Sultan II. Mahmud tarafindan vakfedilmiştir. ${ }^{28}$

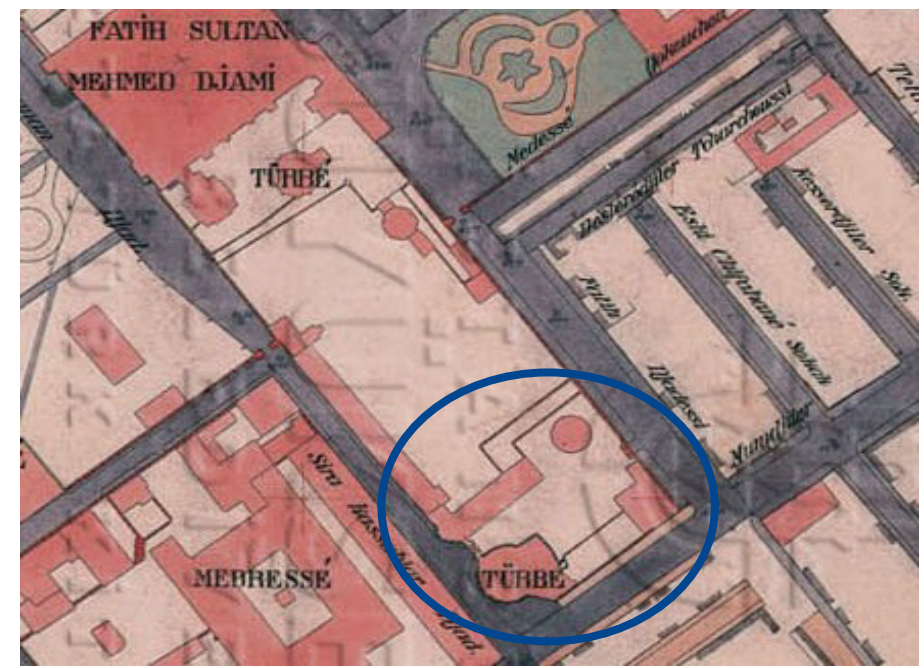

G. 5: Fatih Külliyesi ve Çevresi.

(Alman Mavileri: 1913-1914 I. Dünya Savaşı Öncesi İstanbul Haritaları, K8)

Nakşidil Sultan Külliyesi (1818), Fatih semtinin çekirdeğini oluşturan ilk selâtin camii ve külliyesinin (Fatih Camii ve Külliyesi) haziresinde yer almaktadır. İstanbul'un fethinden sonra Fatih Sultan Mehmed şehrin ortasına Bizans için önem arz eden On

27 Emine İlhanlı, "Sineperver Ayşe Vâlide Sultan, Nakşidil Valide Sultan ve Perstû Valide Sultan Vakıfları" (Yüksek Lisans tezi, Fatih Sultan Mehmet Vakıf Üniversitesi, 2018), 33.

28 Fikret Sarıcaoğlu, "Nakşidil Valide Sultan", Türklük Araştırmaları Dergisi 9 (2001), 108-109; Fikret Sarıcaoğlu, "Nakşidil Sultan”, TDV İslâm Ansiklopedisi, c. 32 (İstanbul: Türkiye Diyanet Vakfı, 2006), 344. 
İki Havari Kilisesi'nin yerine kendi adına 1470 yılında bir cami ve külliye binaları inşa ettirmiştir. Böylece yedi tepeli şehrin en yüksek tepesi üzerine yaptırılan cami ve külliye artık burada yeni bir inancın egemen olduğunu göstermiş ve İstanbul'un silüetine İslamiyet'in ve Türklüğün damgasını vurmuştur. Şehircilik bakımından ortasından cami bulunan benzersiz tasarımla binaların tam simetriye göre yerleştirilmesiyle oluşan yapı topluluğu İstanbul'un en önemli dini ve kültürel merkezini oluşturmuştur ${ }^{29}$.

Fatih Külliyesi’nin taşıdığı dini ve kültürel miras, çevresinin zamanla büyük bir mezarlık alana dönüşmesine sebep olmuştur. Caminin kıble istikametindeki büyük hazireye defin işlemleri 18. yüzyılda yapılmaya başlanmış olup buraya ilk zamanlarda sadece saray ahalisi ve devlet adamları defnedilmiştir. 19. yüzyılda ise sivil definler yapılmaya başlanmıştır. Hanedan mensuplarından Fatih Sultan Mehmed ve eşi Gülbahar Hatun'un türbeleri buradadır. Hazirede çoğu 19. yüzyıla tarihlenen sivil, asker, ulema ve tarikat şeyhleri gibi birçok önemli şahsiyetin kabirleri yer almaktadır. II. Mahmud'un annesi Nakşidil Valide Sultan Türbesi'nin buraya inşa edilmesi ve etrafında bir külliyenin oluşturulmasıyla mezarlık alanı daha da büyümüştür. Sultan Vahideddin'in annesi Gülistu Sultan'ın Türbesi de bu alandadır.

Nakşidil Sultan'ın yapılar topluluğu Fatih Külliyesi'nin güneyindeki hazire üzerinde yer almaktadır. Yapıların bulunduğu arazi güneyden Mıhçılar Caddesi, doğudan Büyük Karaman Caddesi, batıdan Fatih Türbesi Sokağı ile sınırlandırılmışıtır. Külliye elemanları ortak bir avlu etrafına dizilmiştir. Avlunun güneydoğusunda türbe ve sebil, kuzeybatısında sıbyan mektebi bulunurken Fatih Camii yönünde Gülistu Valide Sultan Türbesi ve imaret yapısı vardır.

Külliye cümle kapısı, Fatih semtinin en işlek caddelerinden Büyük Karaman Caddesi'ne bakmaktadır. Kapının doğusunda türbe, batısında ise sebil yer alır. Kuban, Nakşidil Sultan Türbesi’ni Osmanlı mimarisinde Barok üslubu en iyi yansitan türbe olarak nitelendirmiştir ${ }^{30}$. Yine Kuban, türbenin klasik dönem türbelerinin cephe anlayışından oldukça farklı olan tasarımını 19. yüzyıl mimarisinde kentsel karakteri daha belirgin ve daha geniş cepheli kompozisyon fikrinin etkili olmaya başladığını gösteren önemli bir örnek olarak kabul etmiştir. ${ }^{31}$ Külliyenin en gösterişli parçası olan türbe, dıştan on dört kenarlı içten dairesel planlıdır. Caddeye bakan cephesi dalgalı hatları olan sütunlar arasına yerleştirilmiş iki sıra pencere ve cepheden taşarak ön plana çıkan bir mimari tasarıma sahiptir. Alt sıradaki pencereler dikdörtgen formlu basık kemerli olup üst sıradaki pencereler ovaldir. Kuzeydoğu yönündeki giriş cephesi sekiz adet sütunun taşıdığı aynalı tonoz örtülü geniş bir saçak biçimindedir.

29 Semavi Eyice, "Fatih Camii ve Külliyesi”, TDV İslâm Ansiklopedisi, c.12, (İstanbul: Türkiye Diyanet Vakfi, 1995), 244.

30 Kuban, Osmanlı Mimarisi, 548.

31 Kuban, Osmanlı Mimarisi, 548. 
Nakşidil Sultan Sebili türbeye barok bir duvar ile birleşir. Türbe ve sebil arasında basık kemerli giriş kapısı vardır. Yap1, II. Mahmud dönemi cephe sebillerinin en önemli örneklerinden biridir. Üç basamaklı taş kaide üzerine oturan sebil mermer kaplıdır. Yarım daire biçiminde dışa taşkın dört cephesinde basık kemerli büyük pencereler vardır. İnce sütunçelerle birbirinden ayrılan pencerelerin zarif şebekeleri dökme demirden yapılmıştır. Sütunçelerin kenger yapraklı süslü başlıkları konsollara uzanmaktadır. Üzeri kurşun kaplı basık bir kubbe ile örtülen sebilin saçağı oldukça geniş tutulmuştur. Yapıda türbeye göre daha az kullanılan barok öğeler saçak altında yer alan dörtlü kitâbe panoları arasına yerleştirilen kenger yapraklarıdır. Sebilin türbe ile birlikte kurgulanması cephede hareketliliği arttırmıştır.

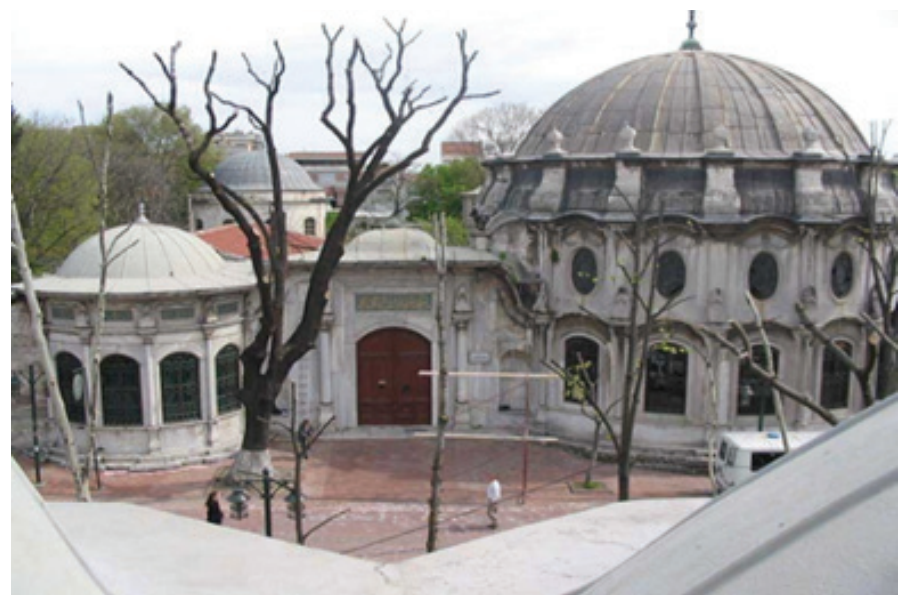

G. 6: Nakşidil Valide Sultan Türbe ve Sebili http://www.web.fomgrup.com/TR/50/projedetay/14.05.2019;22:27

Sıbyan mektebi, türbe ve sebile göre sade bir tasarıma sahiptir. Küfeki taş duvar örülü, iki katlı fevkani mektebin cephelerinde iki sıra pencere dizisi vardır. Türbe ve sebilin sokak dokusu üzerinde bıraktığı hareketli ve dekoratif etkiye karşın mektep cadde üzerinde yüksek ve masif duvarlı yalın cephesiyle zıtlık yaratır.

Osmanlı mimarisinde sıbyan mektepleri külliyelerin önemli bir elamanı olduğu gibi mahalle dokusunun organizasyonu açısından da mühim yapılardır. Külliye içerisinde yer alan sıbyan mekteplerinin en önemli özelliklerinde biri de içinde bulundukları yapı grubundan ayrı tutulmuş olmalarıdır. Genellikle mimari tarz açısından ait oldukları yapı topluluğu ile uyumlu olan bu mektepler sokağa açılan özel girişlere ve kendi içine dönük avlu ve oyun bahçelerine sahiptirler. Daima külliyelerin dış köşesine konumlandırılırlar. Külliyenin diğer elemanları; avlular, bahçeler, ağaçlıklar ve duvar gibi unsurlarla sokaktan mümkün olduğu kadar uzakta inşa edilirken, mektepler yapılardan ayrı düşünülmüş ve daima sokağa yakın yerleştirilmiştir ${ }^{32}$.

32 Özgönül Aksoy, "Osmanlı Devri Sıbyan Mektepleri Üzerine Bir Deneme” (Doktora tezi, İstanbul Teknik Üniversitesi, 1968), 149-150. 


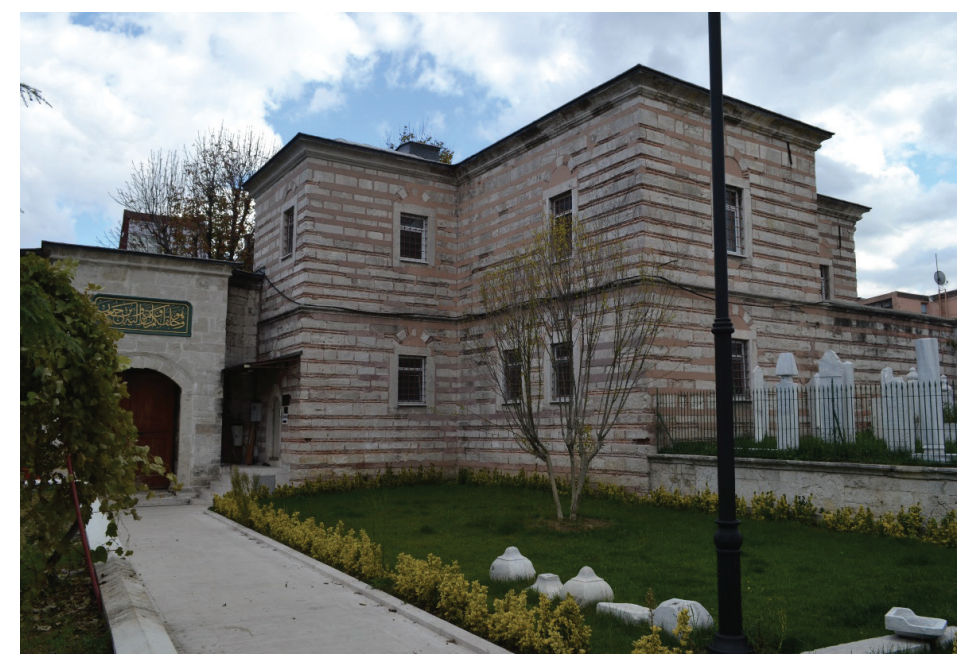

G. 7: Nakşidil Sultan Sıbyan Mektebi (Pınar Şahin Arşivi, 2018)

Nakşidil Sultan Sıbyan Mektebi yerleşme düzeni açısından değerlendirildiğinde diğer yapılardan ayrı tutularak külliye avlusunun kuzeydoğu köşesine Fatih Türbesi Sokak ve Mihçılar Caddesi'nin kesiştiği köşeye inşa edildiği görülmektedir. Avlu içerisinde önünde bulunan bahçe düzenlemesiyle külliye yapılarından ayrı tutulan mektep, hemen yanından sokağa açılan kendine ait bir girişe sahiptir. Nakşidil Sıbyan Mektebi yapı grubunun parçası olduğu kadar mahalle iskânında bir parçası hâline gelmiştir. Mektebin gündelik hayata dönük bir şekilde inşa edilmesi Osmanlı toplumunda eğitimin öneminin mimari açıdan ifadesidir.

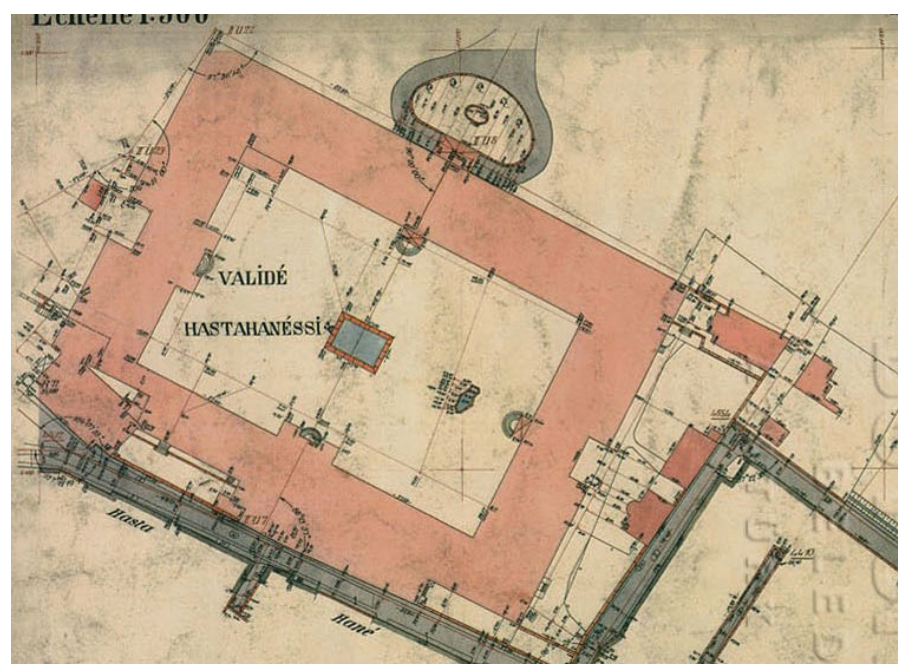

G. 8: Valide Hastanesi.

(Alman Mavileri: 1913-1914 I. Dünya Savaşı Öncesi İstanbul Haritaları, L8-3) 
Saray kadınlarının yaptırdığı diğer külliye Bezmiâlem Gurebâ-yı Müslimîn Hastanesi Külliyesi (1845)'dir. Çapa Arapemini Mahallesi'ne Bezmiâlem Valide Sultan'ın inşa ettirdiği külliyenin merkezini hastane binası oluşturmaktadır. 1826 yılında Osmanlı Devleti'nde, özellikle İstanbul'da ortaya çıkan şiddetli kolera salgını ve 1843 yılında baş gösteren çiçek salgınları hastanenin yapılışının en önemli sebeplerden biridir ${ }^{33}$. Bu dönemde İstanbul'da faaliyet gösteren sağlık kuruluşlarından Fatih Dârüşşifası, Süleymaniye Dârüşşifası, Haseki Hürrem Sultan Dârüşşifası ve Atik Valide Nurbanu Sultan Dârüşşifası'nın yatak kapasitelerinin az olması salgın karşısında sağlık sistemini yetersiz bırakmış, bu durum yeni bir hastanenin kurulmasını gündeme getirmiştir ${ }^{34}$.

Hastanenin inşasının diğer bir sebebi olarak Valide Sultan'ın gördüğü rüya gösterilmektedir. Rivayete göre Valide Sultan rüyasında iki yüz yoksul erkeğe yardımcı olduğunu görmüştür. Rüyası "öyle bir hayır işleyeceksin ki dünya durdukça iki yüz erkek senden hayır ile bahsedecek" şeklinde tabir edilince iki yüz yataklı bir erkek hastanesi kurmaya karar vermiştir ${ }^{35}$.

Sultan Abdülmecid annesinin İstanbul'daki yoksullar için bir hastane yaptırma isteğini dönemin yayın organlarından Takvim-i Vekayi ile halka duyurmuştur ${ }^{36}$. Belirlenen arsa üzerine cami ve çeşme ile birlikte inşa edilen hastanenin açılışı 12 Mart 1847 'de Sultan Abdülmecid ve devlet ricalinin katıldığ 1 büyük törenle yapılmıştır ${ }^{37}$. Vak'anüvis Ahmed Lütfi Efendi padişahın hastane camisinde Cuma namazını kıldıktan sonra açılışını yaparak cami ve müştemilatını gezdiğini kaydetmişti³ ${ }^{38}$.

Vakıf Gureba Hastanesi ihtiyaç sahibi Müslümanlar için inşa edilen, çağın sağlık kuruluşları olan darüşşifa ve bimarhanelerden tamamen faklı özellikte, modern aletler ve doktorlarla donanmış, çağdaş tıbbi kuralların uygulandığı bir kurumdur. Farklılığ1$\mathrm{n} ı$ batılı mimari tasarımı ile de vurgulayan hastane, devletin güçlenme isteği ile yaptığ yeniliklerin ve ortaya çıkan yeni binaların tüm toplumu kapsadığı mesajını halka ulaştıran mimari bir simgedir. Gurebâ-yı Müslimîn Hastanesi Külliyesi’nin (1845) inşası hem tıp hem de mimarlık tarihimiz açısından önemli bir adımdır. Modern sağlık kurumlarının yeni modelini teşkil eden bu yapının tesis edileceği yerin titizlikle seçildiği görülmektedir. Hastane şehir dışında, havadar bir mekân olan Yenibahçe civarındaki Nakkaş Paşa arsası üzerine kurulmuştur.

33 Şentürk, "Bezmiâlem Vâlide Sultan'ın Hayatı ve Hayır Eserleri," 18.

34 Nuran Yıldırım, Gureba Hastanesinden Bezmîalem Vaklf Üniversitesi'ne (From Charity Hospital to the Bezmialem Foundation University) (İstanbul: Bezmiâlem Vakıf Üniversitesi Yayınları, 2013), 22.

35 Kâzım İ. Gürkan, Bezmiâlem Valide Sultan Vakıf Gureba Hastanesi Tarihçesi (İstanbul: Özışık Matbaası, 1967), 13.

36 Yıldırım, Gureba Hastanesinden Bezmîalem Vakuf Üniversitesi'ne, 22.

37 Ali Akyıldız, Haremin Padişahı Valide Sultan Harem 'de Hayat ve Teşkilat (İstanbul: Timaş Yayınları, 2017), 455.

38 Ahmed Lütfi Efendi, Vak'anüvis Ahmed Lütfi Efendi Tarihi, haz. Yücel Demirel (İstanbul: Yap1 Kredi Kültür Sanat Yayıncilık, 1999), 6-7-8: 1202-1203. 


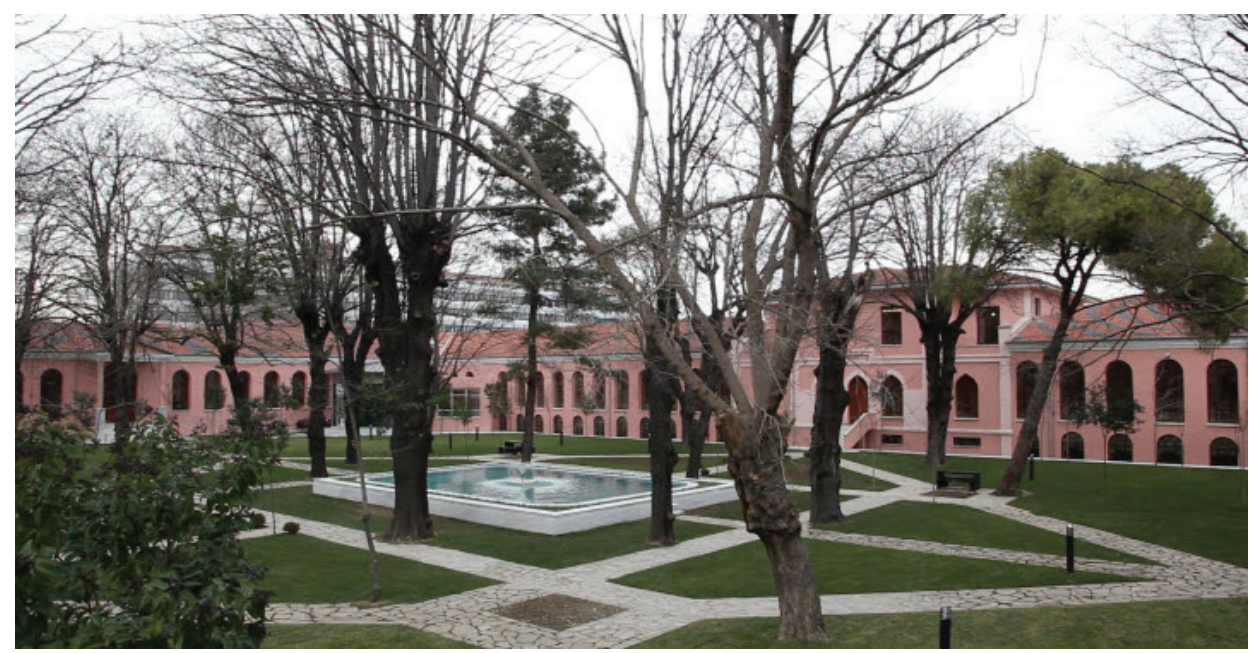

G. 9: Bezmiâlem Gurebâ-yı Müslimîn Hastanesi

https://bezmialem.edu.tr/tr/Sayfalar/idari/uluslararasi-iliskiler-ofisi/fotograflarla-bezmialem. aspx09.12.2021:22.15

Arsanın üç tarafında bulunan Baltacı Odaları diye bilenen evler ve Ebubekir Paşa Bostanı eklenerek hastanenin kaplayacağı alanın sınırları belirlenmiştir. Ayrıca Topkapı'ya giden ana yolun iki yanındaki arsalar da eklenerek bu alan genişletilmiştir $^{39}$. Bağ ve bostanlarla kaplı bir bölgeye inşa edilen büyük sağlık kompleksi çevresinde zamanla yerleşim alanlarının oluşmasında etkili olmuştur. Hastaların rahatı için gürültüden uzak ve suyun kolayca getirilebileceği bir mevkide inşa edilmesi fikri o dönemin yapı planlamasında ne kadar hassas davranıldığını göstermesi açısından önemlidir ${ }^{40}$. Yenibahçe semtinin demografik ve fiziksel büyümesinde etkili olan Vakıf Gureba Hastanesi aynı zamanda ulaşımın gelişmesine de vesile olmuştur. Sultan Abdülmecid hastane inşasının gündeme gelmesiyle birlikte bu bölgedeki caddelerin tanzim edilmesini emretmiştir ${ }^{41}$.

Osmanlı tarihinde "hastane" adı ile anılan ilk sivil sağlık kuruluşu olma ayrıcalığını taşıyan Vakıf Gureba Hastanesi medrese planlı darüşşifalar ve bimarhanelerle modern kışla modelleri arasında bir tasarıma sahiptir. 19. yüzyıl başında İstanbul'da bulunan sağlık kuruluşlarından Fatih Külliyesi Şifahanesi (1470), Süleymaniye Külliyesi Darüşşifas1 (1556), Haseki Hürrem Sultan Bimarhanesi (1551) ve Nurbanu Sultan Bimarhanesi (1579) kare orta avlulu revaklı oda sistemini içeren planda yapılmıştır. Bezmiâlem Hastanesi bu plana yakın olmakla birlikte o ödemde en çok kışla yapımında kullanılan dikdörtgen avlulu koğuş sistemine oturan bir şemada inşa edilmiştir.

39 Yıldırım, Gureba Hastanesinden Bezmîalem Vakıf Üniversitesi’ne, 23.

40 Şentürk, "Bezmiâlem Vâlide Sultan’ın Hayatı ve Hayır Eserleri”, 20.

41 Kenan Göçer, "Sosyo-Ekonomik Yönleriyle Bezmiâlem Vâlide Sultan Vakıf Gureba Hastahanesi” (Doktora tezi, Marmara Üniversitesi, 2012), 161. 
Hastanenin darüşşifa ve bimarhanelerden en önem farkı yeni bir yönetmeliğe ve bakım koşullarına sahip olmasıdır. Geleneksel sağlık kurumları tipolojisinden farklılaşan bu yapısal ve fonksiyonel kurum, Bezmiâlem'in baniliğini üstlendiği büyük inşa faaliyeti ile kent dokusunda yerini almıştır ${ }^{42}$.

Bezmiâlem Külliyesi (1845) klasik külliye anlayışının dışında 19. yüzyılda içinde hastane bulunan bir yapı topluluğu olarak önemlidir. Osmanlı mimarisinin temelini oluşturan camii merkezli kuruluşlardan farklı olarak hastane yapısının ön plana çıkarıldığı bir külliye olarak inşa edilmiştir. Külliyenin inşasında görevlendirilen Seyyid Abdülhalim Efendi yapıları topoğrafyaya uygun olarak planlamıştır. Hastaneyle birlikte tasarlanan cami, külliye ile organik bir bütünlük içinde inşa edilmiştir ${ }^{43}$.

Saray kadınlarının inşa ettirdiği önemli bir yapı olan Bâlâ Külliyesi İstanbul'un en eski semtlerinden Silivrikapı'da ${ }^{44}$ Tekke Maslağı Sokağı ile Bâlâ Tekkesi Sokağı'nın etrafında kurulmuştur. Bâlâ Külliyesi'nin (1863) kuruluşu 15. yüzyıla dayanmaktadır. Kaynaklarda İstanbul'un fethine katılmış olanlardan Bâlâ Süleyman Ağa'nın 14531457 y1lları arasında külliyenin bugün bulunduğu yerde bir mescid ve kuyu yaptırdığ1, ölümünden sonra da mescidin yanına defnedildiği ifade edilmektedir ${ }^{45}$. Hadikatü'lCevâm 'i' de yapının ismi Bâlâ Mescidi olarak anılmakta ve bu yıllarda (1768) harap olduğu bilgisi verilmektedir ${ }^{46}$. 1900'lü yılların başında söz konusu mescid, Rıfaiyye Tarikatı'na bağlı “Bala Yokuşu Zaviyesi” olarak geçmektedir"47.

42 Afife Batur, "Bezmiâlem Gurebâ-yı Müslimîn Hastahanesi Ek Yapıları Mimar Kemaleddin Bey Tasarımları", 2010 Vakıf Medeniyeti İstanbul Yılı ve Vakıflar Haftası Etkinlikleri (Ankara: Başbakanlık Vakıflar Genel Müdürlüğü Yayınları, 2011), 120.

43 Gönül Cantay, "XIX. Yüzyılda Kurumsallaşma ve Hastahaneler- I", Fatih Sultan Mehmet İnsan ve Toplum Bilimleri Dergisi I (2013), 117; Gönül Cantay, Osmanlı Külliyelerinin Kuruluşu (Ankara: Atatürk Kültür Merkezi Başkanlığı Yayınları, 2002), 102.

44 Bâlâ Külliyesi günümüzde Mevlanakapı Mahallesi sınırları içerisindedir.

45 Muhiddin Hattatoğlu, "İstanbul Silivrikapı'da Topçubaşı Balâ Süleyman Ağa Mimari Manzumesi”, Vakıflar Dergisi 4 (1958), 183-191.

46 H. Ayvansarâyî, S. Besîm Efendi, A. Sat'1 Efendi, Hadikatü'l- Cevâm 'i, 99.

47 M. Baha Tanman, "Bâlâ Külliyesi”, TDV İslâm Ansiklopedisi, c. 4 (İstanbul: Türkiye Diyanet Vakfi,1991), 554. 


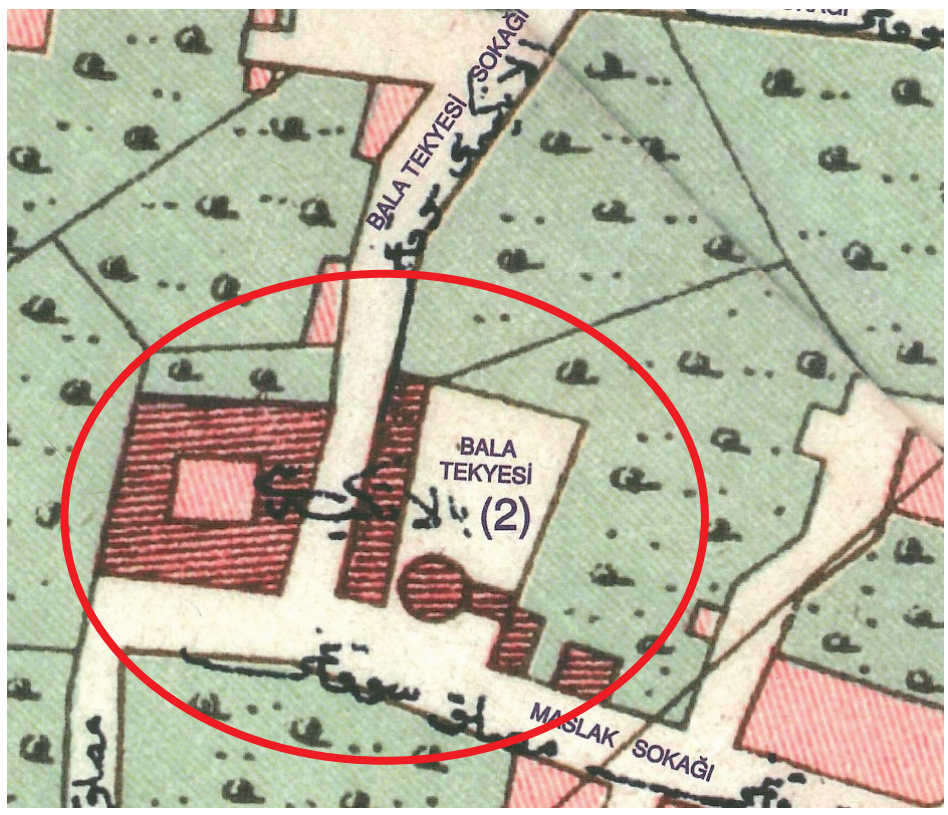

G. 10: Bâlâ Tekkesi.

(M. Ulvi Günpınar, vd., XIX. Yüzyıldan XX. Yüzyıla Necib Bey Haritaları'ndan Günümüze Öncesi ve Sonrası, 86.)

Söz konusu mescid zamanla kullanılmaz hâle gelmiş 19. yüzyılda çeşitli katkılarla genişleyerek günümüzdeki "Bâlâ Süleyman Ağa Külliyesi” hâlini almıştır. Külliye ve çevresindeki semtin oluşmasına katkıda bulunan üç Osmanlı saray kadınıdır. İlk olarak Sultan Abdülaziz döneminde Sultan II. Mahmud'un hareminden Sazkâr Kalfa, 1863 yılında yapıyı öncekinden daha büyük ve geniş, bir tekkenin cami-tevhidhanesi olarak yeniden inşa ettirmiştir. Bu süreçte cami-tevhidhaneye bitişik bir türbe, harem dairesi, derviş hücreleri mutfak, kiler, su hazinesi ve müştemilat da yapılmıştır. Söz konusu inşaatlardan hemen sonra 1864'te Sultan Abdülmecid'in dördüncü kadını Perestû Kadınfendi tekke binalarının yanına Bâlâ Mektebi ismi ile bilinen okulu yaptırmış ve 1892 'de de sebil-muvakkithane-çeşme ekletmiştir ${ }^{48}$.

II. Mahmud'un kızı Âdile Sultan 1894 depreminde zarar gören Bâlâ Tekkesi'nin cami-tevhidhane-türbe ve harem binalarını genişleterek yeniden yaptırmıştır. Derviş hücreleri, selâmlık mekanları ve mutfağı barındıran yapı grubu da II. Abdülhamid tarafından ihya edilmiştir. Perestû Kadınefendi bu yapının duvarına 1895 yılında bir çeşme yaptırmışıır ${ }^{49}$. Osmanlı saray kadınlarının 19. yüzyıl boyunca gerçekleştirdikleri inşa faaliyetleri ile iki sokak ve üç köşeyi içine alan cami, türbe, meşruta, tekke, muvakkithane, çeşme ve sebil grubu ile pitoresk bir çevre oluşmuştur.

48 Tanman, "Bâlâ Külliyesi," 554-555.

49 Tanman, "Bâlâ Külliyesi," 555. 


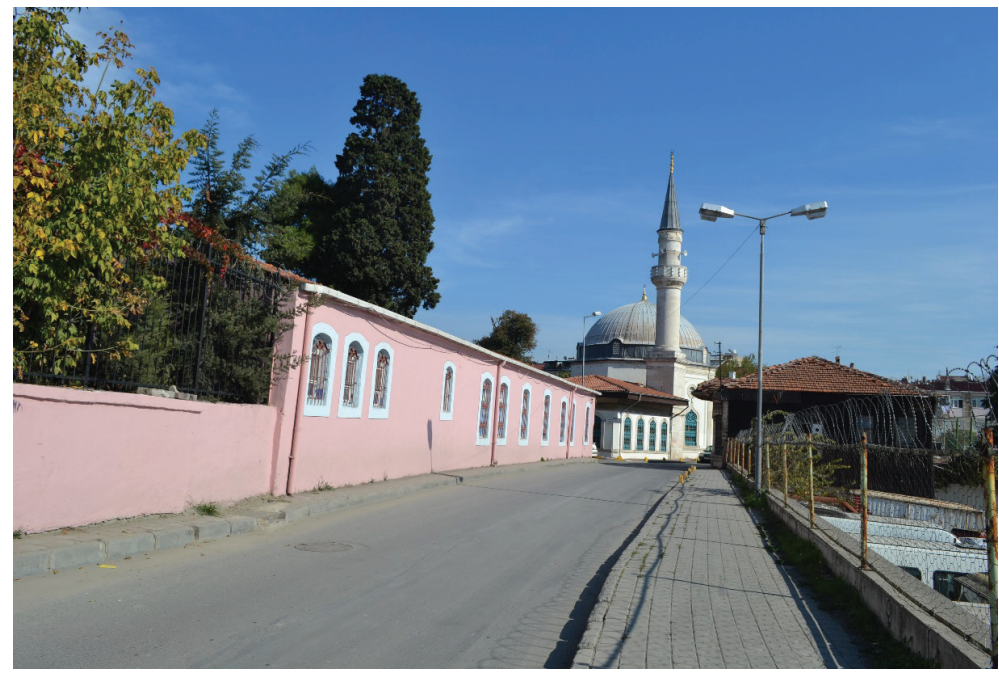

G. 11: Bâlâ Külliyesi genel görünüşü. (Pınar Şahin Arşivi, 2018)

Bâlâ Külliyesi (1863) mimari değeri yüksek bir manzume olduğu gibi şehircilik aç1sından da önemli bir örnektir. Oldukça geniş bir mimari programa sahip olan yapılar topluluğu, dik kesişen Tekke Maslağı Sokağı ile Bâlâ Tekkesi Sokağı'nın etrafina yerleştirilmiş̧ir. Tekke Maslağı Sokağı üzerinde sebil-muvakkithane-çeşme grubu, Bâlâ Tekkesi Sokăğ'nın üzerinde batıda cami-tevhidhane-türbe; doğuda harem binası, derviş hücreleri, selâmlık ve mutfak bölümü bulunmaktadır. Yapıların arasında kalan yollar hem binaların sirkülasyonunu sağlamış hem de içinde bulunduğu mahallenin sokak dokusunu oluşturmuştur. İsmini tekkeden alan bu sokaklar yapı topluluğunun, cami merkezli külliyelerden daha çok mahalle dokusu ile bütünleşmesini sağlamıştır. Bâlâ Külliyesi (1863), gelişimi 12. yüzyıla kadar dayanan tarikat külliyelerinin geç döneme ait önemli bir örneğidir. Aynı zamanda tekkelerde bulunan cami-tevhidhane, türbe, hazire, harem ve selâmlığın yanı sıra sebil, çeşme, muvakkithâne ve mektep gibi bölümleri de bulunduran külliye, 17. yüzyılda Osmanlı devletinin mali durumunun zayıflamasına bağlı olarak ortaya çıkan küçük şehir külliyelerinin gelişim süreci içinde yer almaktadır ${ }^{50}$.

Bâlâ Külliyesi (1863) Silivrikapı semtinin çekirdeğini oluşturan ve burada kurulan en eski külliyedir. İstanbul'un fethi sırasında stratejik bir öneme sahip olan Silivrikapı' da fetihten sonra imar ve iskân politikası başlatılmıştır. İzlenen bu politika kapsamında Silivrikapı' da yürütülecek imar faaliyetlerini Fatih'in Topçubaşısı Süleyman Ağa üstlenmiş ve iskân siyasetinin bir gereği olarak bölgeye Arnavutlar yerleştirilmiştir. Fatih döneminde başlayan imar-iskân faaliyetleri 16. ve 17. yüzyıllarda da devam etmiş olup camiler etrafında yeni yapı toplulukları inşa edilmiştir ${ }^{51}$. Nitekim

50 M. Baha Tanman, “İstanbul Tekkelerinin Mimari ve Süsleme Özellikleri Tipoloji Denemeleri” (Doktora tezi, İstanbul Üniversitesi,1990), 732.

51 Ş. Pınar Yavuztürk, "Silivrikapı Semti”, İstanbul'un Kitabı Fatih (İstanbul: Fatih Belediyesi Yayınları, 2013),1: 287, 292. 
Silivrikapı'da Bâlâ Süleyman Ağa tarafından inşa edilen külliye, Bâlâ Camii'nin etrafinda teşekkül etmiştir. Bâlâ Süleyman Ağa Camii, çevresinde kendi ismiyle anılan bir mahalle olan Bâlâ Mescidi Mahallesi’nin oluşmasını sağlamıştır ${ }^{52}$.

Bâlâ Külliyesi tarikat yapılarının yoğun olduğu bir bölgede kurulmuştur. Binaların bulunduğu sur içi hattı Osmanlı dönemi boyunca seyrek yerleşmelere sahne olmuştur. Marmara Denizi'nden Topkapı'ya uzanan bu kuşakta çok sayıda tarikat yapısının yanı sıra bostanlar arasına serpiştirilmiş mesken grupları ile küçük ölçekli hayır yapıları da dikkat çekmektedir ${ }^{53}$. Günümüzde külliyenin yakın çevresinde bulunan Hüsnümelek Hanım Çeşmesi, Bezmîalem Çeşmesi, Abdullah Ağa Çeşmesi, Lâlezar Camii, Hadım İbrahim Paşa Camii (1551), Karagöz Mehmet Paşa Camii, Sitti Hatun Camii, Veledi Karabaş Camii (1893), Körükçü Tekkesi ve Safiye Sultan Çeşmesi (1726) hayır yapılarından bazılarıdır.

Padişah annelerinin İstanbul'da yaptırdığı en son külliye Aksaray Meydanı'nın kuzeybatısına inşa edilen Valide Külliyesi (1871)'dir. Bânisi Sultan Abdülaziz'in annesi ve II. Mahmud'un eşi Pertevniyal Valide Sultan'dır. Zengin bir vakfa dayalı olarak tesis edilen yapılar topluluğu, Hacı Mustafa Ağa Camii ya da Kâtip Camii olarak bilinen harap durumdaki yapının arsası üzerine kurulmuştur. Külliye 1867-1871 yılları arasında inşa edilmiş olup cami, mektep, türbe, türbedar odası, kütüphane, muvakkithane, karakol, sebil, çeşmeler ve yedi adet dükkândan oluşmaktadır ${ }^{54}$.

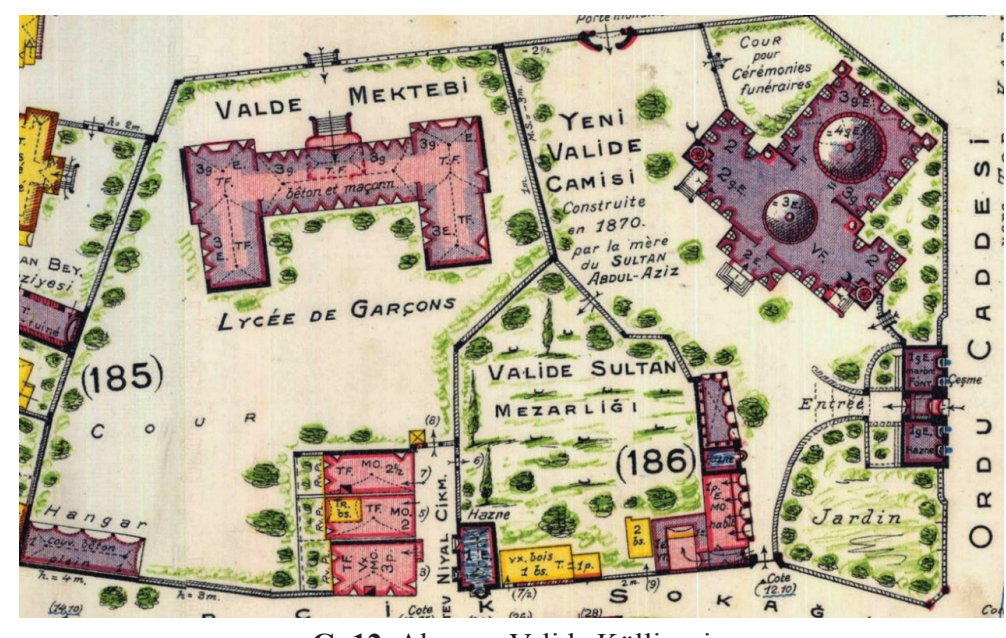

G. 12: Aksaray Valide Külliyesi

(J. Pervititch, Sigorta Haritalarında İstanbul, 53)

52 E. Hakkı Ayverdi, Fatih Devri Sonlarında İstanbul Mahalleleri Şehrin İskânı ve Nüfusu (Ankara: Vakıf Umum Müdürlüğü Yayınları, 1958), 14.

53 Tanman, “İstanbul Tekkelerinin Mimari ve Süsleme Özellikleri Tipoloji Denemeleri,” 724.

54 Doğan Yavaş, "Pertevniyal Valide Sultan”, TDV İslâm Ansiklopedisi, c. 34 (İstanbul: Türkiye Diyanet Vakfı, 2007), 241. 
1826 yılında gerçekleşen ve Osmanlı tarihinde Vak'a-yi Hayriye olarak adlandırılan yeniçeriliğin kaldırılması olayı Sultan II. Mahmud'un eşi Pertevniyal Kadın üzerinde büyük bir etki yapmış ve Valide Sultan olduğunda olayın gerçekleştiği Aksaray'daki Yeniçeri kışlalarının bulunduğu alan üzerinde eşi anısına bir cami inşa ettirmiştir ${ }^{55}$.

"Vak'a-i Hayriye"den sonra Aksaray terk edilmiş ve tenha bir yer hâline gelmiştir. 1845 y1lında buradan geçen İngiliz seyyah Charles White bölgeyi '1ssız' bir yer olarak tanımlamaktadır: "1453-1826 yılları arasında binalar, avlular, çeşmeler ve dükkanlarla işgal edilen bu devasa alan, şimdi el değmemiş bir doğa; kesişen dar duvarlı yollar, küçük konutlar ya da bahçelerle bölünmü̈ştür..." ${ }^{56}$ Aksaray sürekli gerçekleşen yangınlar sebebiyle de ayrı bir ün kazanmıştır. İstanbul'da yangınlar sık sık gerçekleşmektedir ve şehrin en çarpıcı tarihî felaketleri arasındadır. İstanbul'daki belediye kuruluşlarının gelişimi için ana kaynak olan Mecelle-i Umûr-ı Belediyye'de Osman Nuri Ergin, yangınları 'tarihsel felaket' olarak adlandırmaktadır ${ }^{57}$. Aksaray'ın kentsel dokusunu etkileyen en büyük yangın 24 Kasım 1854 'te meydana gelmiştir ${ }^{58}$. Dönemin tarihçilerinden Ahmed Lütfî Efendi yangın sonrasındaki çalışmaları detaylı bir şekilde anlatmıştır. Lütfî Efendi, başkentteki çalışmaların ardından "düzenli sokaklar ve caddeler organizasyonunun" ilk defa Aksaray'da uygulandığını ve düzenlemelerin avantajlarının görüldükten sonra diğer alanlarda da kademeli olarak geçildiğinin bilgisini vermiştii ${ }^{59}$.

1854 yılında gerçekleşen ve Mecelle'ye göre 748 binay $1^{60}$ tahrip eden yangın sadece Aksaray'ın dönüşümünde etkili olmamış, aynı zamanda İstanbul'un kentsel tasarım tarihinde de dönüm noktası olmuştur. Yangından bir sene sonra 1856'da Osmanlı Devleti harap olan bu bölgeyi araştırmak ve alternatif bir kentsel plan sunmak için İtalyan mühendis Luigi Storari'yi görevlendirmiştii ${ }^{61}$. Böylece ilk defa büyük bir yangından sonra hükümet kentsel doku için yeni bir plan başlatmıştır.

55 Caminin kitabesinde Sultan II. Mahmud'un ruhu için yaptırıldığı belirtilmiştir. Nurullah Delibaş, Kitâbelerin Kitabı Fatih. çev. Mehmet Samsakçı ve Murat Ali Karavelioğlu (İstanbul: Fatih Belediyesi Yayınları, 2016), 404-405.

56 White, Tree Years in Constantinople; or Domestic Manners the Turks in 1844, 3:260-262.

57 Osman Nuri Ergin, Mecelle-i Umûr-ı Belediyye (İstanbul: İstanbul Büyükşehir Belediyesi Yayınları, 1995), 1:11-13.

58 Osman Nuri Ergin, Mecelle-i Umûr-ı Belediyye (İstanbul: İstanbul Büyükşehir Belediyesi Yayınları, 1995), 3:1228.

59 Ahmed Lütfî Efendi, Vak'anüvis Ahmed Lütfì Efendi Tarihi, yay. Münir Aktepe (İstanbul: İstanbul Üniversitesi Yayınları, 1984), 9: 131.

60 Ergin, Mecelle-i Umûr-l Belediyye, 3: 1228.

61 Zeynep Çelik 19.Yüzyılda Osmanlı Başkenti ve Değişen İstanbul, çev. Selim Deringil (İstanbul: Türkiye İş Bankası Kültür Yayınları, 2016), 69. 


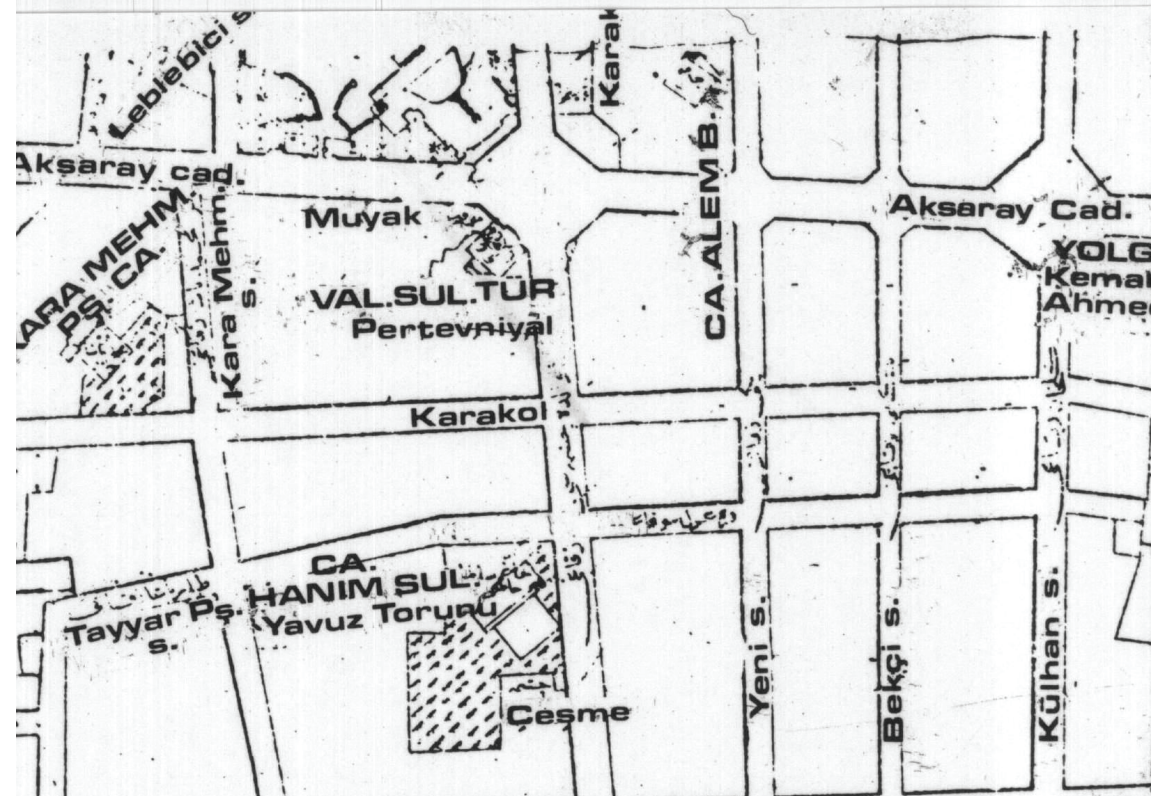

G. 13: Aksaray Meydan1 1870.

(E.H. Ayverdi, XIX. Asırda İstanbul Haritas1, C-3)

Önerilen planın ana özelliklerinden biri, iki ana arterin birbirleriyle açıça kesişerek arterin öneminin arttırılmasıdır. Unkapanı-Yenikapı yolu ve Divanyolu'nun kesişme noktası köşelerinin eklemlenmesi ile vurgulanmış ve batılı tarzda olmasa da Osmanlı'da kent dokusu içerisinde ilk defa küçük bir meydan oluşturulmuştur. Bu meydandan Journal de Constantinople'de 'belle place' (güzel bir meydan) olarak bahsedilmiştir ${ }^{62}$. Yeni meydan kavşağı, Avrupa kentsel planlama ilkelerinin güçlü bir yansıması olarak görülmüş ve Pertevniyal Valide Sultan'ın oğlu Abdülaziz döneminde gerçekleşen Tarihî Yarımada'nın kentsel dönüşümü için de özellikle ilham verici olmuştur $^{63}$. Bu alanın tam bir meydan özelliği kazanması Valide Sultan'ın 1867-1871 yılları arasında inşa ettirdiği külliye sayesinde gerçekleşmiştir. Meydanın kuzeybatısına cami, mektep, muvakkithane; güneybatısına türbe konumlandırılmıştır.

62 Çelik, 19.Yüzyılda Osmanlı Başkenti ve Değişsen İstanbul, 69-70.

63 Zeynep Çelik, The Remarking of Istanbul Potrait of an Ottoman City in the Nineteenth Century, (Berkley CA: University of California Press, 1993), 55. 


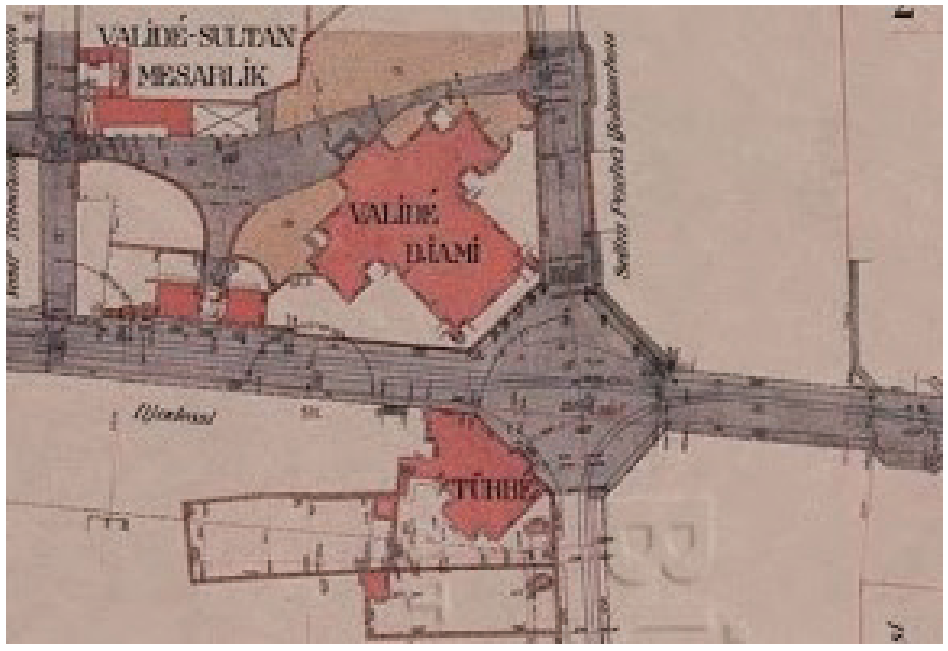

G. 14: Aksaray Meydan1.

(Alman Mavileri :1913-1914 I. Dünya Savaş1 Öncesi İstanbul Haritaları, K6/2)

Kuban, Valide Camii'nin Aksaray şehir meydanına hâkim konumunu yükseklik vurgusu ağır basan oranlarıyla; cephelerdeki plastırlar, yüksek kubbe tambur, merkezi alınlıkları ile caminin bir 'kent simgesi' olduğunu belirtmiştir Buna ek olarak Kuban dönemin örneklerinden farklı olarak harimin boyutlarının büyümesine karşın hünkâr dairesinin boyutlarının sınırlı kalmasının camiye has bir özellik olduğuna dikkat çekmiştir ${ }^{64}$.

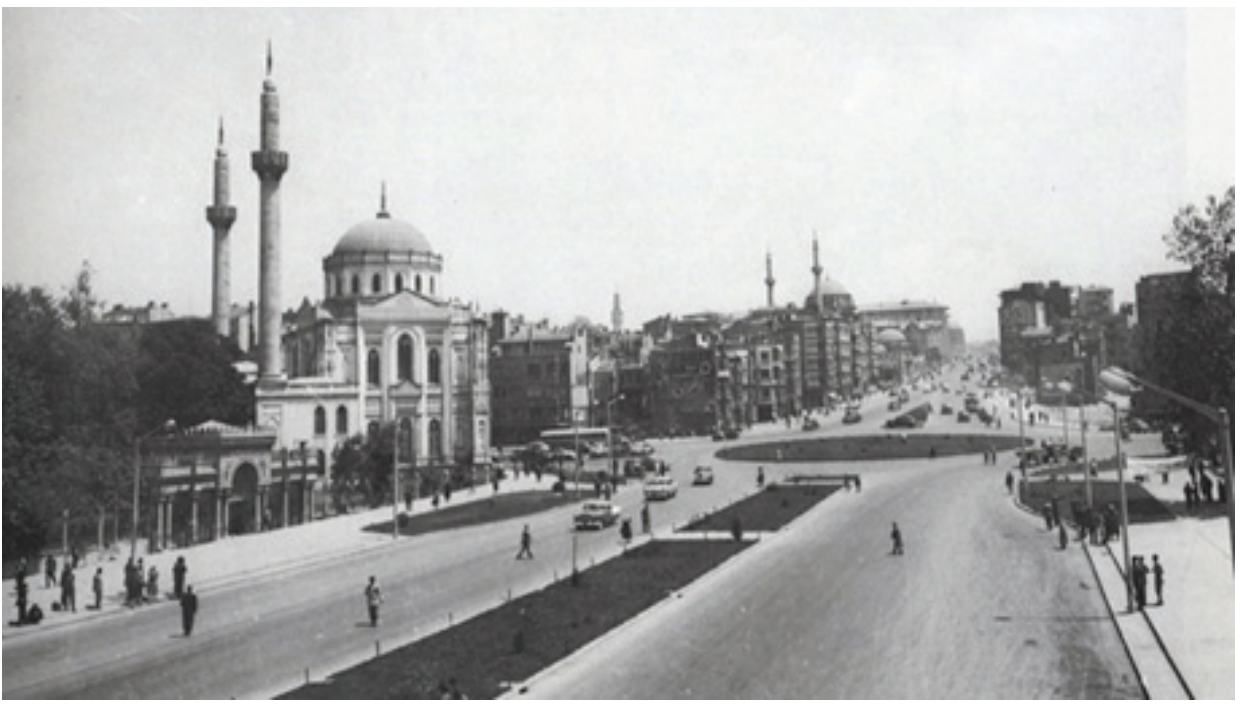

G. 15: Aksaray Meydan1.

http://www.eskiistanbul.net/5784/aksaray 14.10.2018/20.30

64 Kuban, Osmanlı Mimarisi, 640. 
Aksaray’ın kentsel dönüşümünün yarattığı etki dönemin gazetelerinde de konu edilmiştir. Pertevniyal Valide Sultan Camii’nin açılmasından üç yıl sonra 16 Eylül 1875 tarihli Çaylak gazetesinde geçen ifadeler Aksaray’ın popüler bir kent merkezi olduğunu göstermektedir:

“Aksaray Caddesi... burada ve orada kahvehaneler, çay tüccarlarl, eczacılar, tütün satıcıları, kuaförler ve diğer esnaf sahipleri tarafindan aydınlatılan gaz lambaları ile güzel bir şekilde aydınlatıllyor. Özellikle arabaların, caddede yukarı ve aşağı yürüyen kadın ve erkek grupları arasında geçişi parlaktır, çünkü bu arabalar kandil ile aydinlatılır..." ${ }^{\circ 5}$.

Aksaray geç Tanzimat dönemi kentsel dönüşümün ana mekânlarından biri olmuştur. Pertevniyal Valide Sultan'ın külliyenin inşasından önce 1862'de bu alanda inşa ettirdiği çeşme Tarih-i Lütfi' de de belirtildiği üzere bir dört yol ağzı çeşmesiydi ve meydana nitelik kazandiran unsurlardan biriydi ${ }^{66}$. Pertevniyal Valide Sultan bu çeşmeden sonra Aksaray'ın kentsel dokusunu daha da şekillendirecek olan cami kompleksi ile bölgeye damgasını vurmuştur.

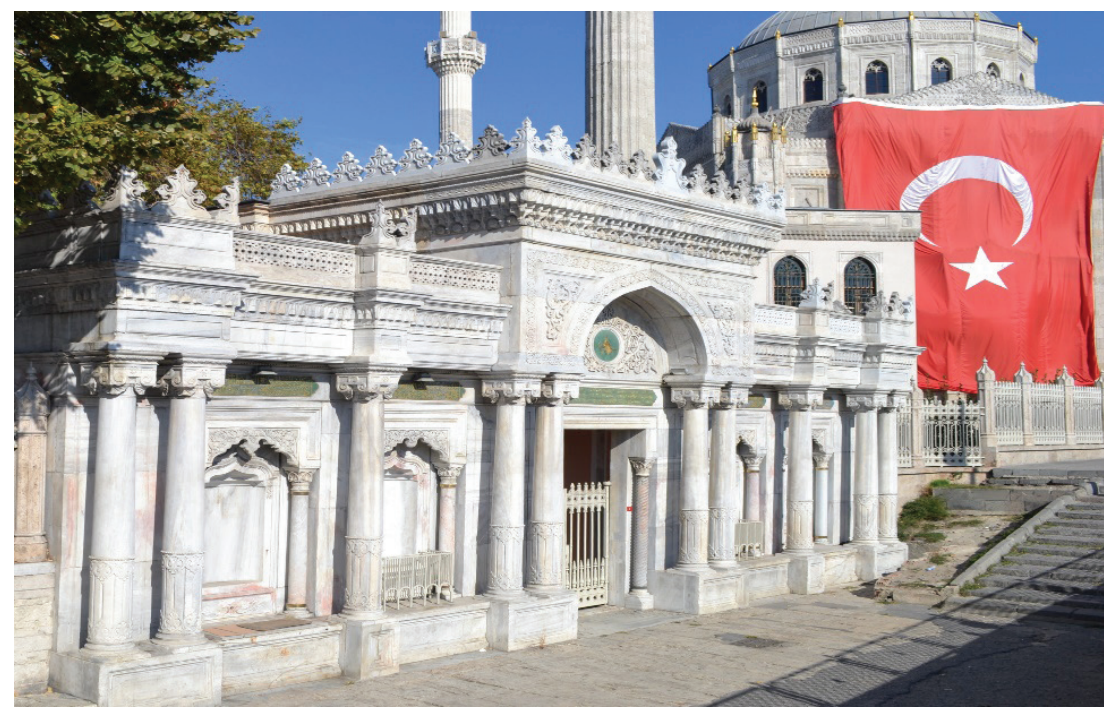

G. 16: 1862 tarihli Pertevniyal Valide Sultan Çeşmesi (Pınar Şahin Arşivi, 2018)

65 "Aksaray Caddesi kahvecilerin, çaycıların, eczacıların, tütüncülerin, perukarların veya sair bu gibi dükkâncıların câbecâ yaktıkaları gaz ile pek güzel tenvir edilip hele bir takımı yukarıya bir takımı aşağıya doğru yayan olarak fevc fevc gelip gitmekte olan kadın ve erkeklerin arasında iki tarafina renkamiz kandil ikad ve derunlarına yapma bebek gibi tuhaf tuhaf hotozlu kadınlar ikâd olunan arabaların geçişi doğrusu pek parlaktır." (Çaylak, 16 Eylül 1292, 3), Bk. Nezihe İdemen, "1869-1876 Yılları Arasında Yayınlanan Mizah Gazetelerinde İstanbul Hayatı", (Yüksek Lisans tezi, İstanbul Üniversitesi,1994), 345.

66 Ahmed Lütfî Efendi, Vak'a-nüvis Ahmed Lütfí Efendi Tarihi, haz. Münir Aktepe (Ankara: Türk Tarih Kurumu, Yayınlar1,1988) 10: 80-81. 
Uşar'ın verdiği bilgilere göre Pertevniyal Valide Sultan'ın kethüdası Hüseyin Bey ile geçen bir yazışmada, Valide Sultan külliyenin bileşenlerinin bireysel pozisyonları hakkında görüşlerini açıkça bildirmiş ve türbe ile caminin Aksaray Meydanı'nın köşelerine hizalanmasını istemiştir. Bu yazışma valide külliyesinin inşasıı sırasında Aksaray Meydanı'nın özel olarak tasarlandığını göstermektedir Aynı süreçte Kethüda Hüseyin Bey külliye etrafındaki sokakların durumuna ilişkin de bilgi vermesi valide sultanın bölgeyle özel olarak ilgilendiğini göstermektedir ${ }^{67}$. Valide Camii'nin açılış tarihi olan 1872'de Eminönü-Aksaray atlı tramvayının hizmete girmesi ve caminin önünden geçmesi dikkat çekicidir ${ }^{68}$. Aksaray'ın kentsel imgesi üzerinde modernleştirici bir etkiye sahip olan ulaşım sistemi muhtemelen Aksaray Valide Sultan Külliyesi ile çevresinin etkileşimini ve bağlantısını kuvvetlendirilmek için yapılmıştır. Cumhuriyet döneminde Aksaray Valide Cami ve Külliyesi’nin (1871) meydan düzenlemesindeki konumları müdahale görmüş ve alanın tarihî kimliği önemli oranda hasar görmüştür. Türbe 1926-1929 yılında tramvay çalışmaları sırasında geriye alınmış 1958 yılındaki şehircilik çalışmaları sırasında yıktırılmıştır. 1967'den sonra da günümüzde bulunduğu yere inşa edilmiştir. 1971 yılında yapılan üst geçit ile de meydan kimliğini tamamen kaybetmiştir.

\section{Sonuç}

19. yüzy1l Osmanlı toplumunda ve devlet teşkilatında modernleşme hareketlerinin başladığı bir dönemdir. III. Selim (1789-1808), II. Mahmud (1808-1839) ve Sultan Abdülmecid (1839-1861) döneminde batılılaşma çalışmaları hız kazanmıştır. 1839 yılında ilan edilen Tanzimat Fermanı'nın gerektirdiği yenilikleri uygulanmak için, imar ve şehircilik çalışmaları başta başkent İstanbul olmak üzere İmparatorluğun tüm kentlerine dalga dalga yayılmıştır. İlk belediye teşkilatı kurulmuş şehrin planında önemli değişiklikler yapılmış, yerleşim alanları ve inşa faaliyetlerinin düzenlenmesi için ebniye nizannameleri çıkarılmıştır. İstanbul'u modern bir kent görünümüne kavuşturma çalışmalarının yoğunluk kazandığı 19. yüzyılda Osmanlı saray kadınları devlet desteği ve kurdukları vakıflar eliyle önemli inşa projeleri gerçekleştirmiştir. Hanım sultanlar modernleşme sürecinde devletin ve toplumun ihtiyacı olan yapıları inşa ettirmişlerdir.

19. yüzyılda Osmanlı saray kadınları için inşa edilen erken tarihli yapılardan Şah Sultan Külliyesi (1800) ve Nakşidil Sultan Külliyesi (1818) İstanbul'un dini merkezlerine kurulmuştur. Türbe, sıbyan mektebi, sebil ve çeşmeden oluşan Şah Sultan Külliyesi (1800) Edirnekapı'dan Eyüpsultan merkezine uzanan eski tarihî yolun

67 Bahar Bilgin Uşar, "The Aksaray Pertevniyal Valide Sultan Complex: Reflections on the Patronage of a Nineteenth Century Valide Sultan," (Yüksek Lisans tezi, Koç Üniversitesi, 2016), 119-120.

68 The Levant Herald Gazetesi'ne göre tramvay caminin aç1lışından önce 5 Nisan 1872'de hizmete girmiştir. The Levand Herald, 5 April 1872, No: 40, pp.158-159. https://archives.saltresearch.org/handle/123456789/129254 2 Mayis 2020,19:49 
kenarında ve semte girişte yer alır. Günümüzde Feshane Caddesi olarak geçen ana cadde üzerinde sıralanan külliye yapıları sokağın görüntüsünü tamamlayan dekoratif bir mimari tasarıma sahiptir. Külliye kapısının kuzeyinde yer alan sebil-i küttap Kahire'de birçok örneği bulunan ve 16. yüzyılda İstanbul'da da görülen sebil-i küttap kompozisyonlarının Eyüpsultan'daki tek örneğidir. II. Mahmud'un annesi için inşa edilen türbe, sıbyan mektebi, sebil, imaretten oluşan Nakşidil Sultan Külliyesi (1818) ise Fatih semtinin çekirdeğini oluşturan ilk selâtin camii ve külliyesinin haziresine konumlandırılmıştır. Külliyenin en gösterişli parçası olan Nakşidil Sultan Türbesi Osmanlı mimarisinde barok üslubun en iyi yansıtıldı̆̆ 1 türbedir.

19. yüzyılda yaptırılan diğer önemli külliye yapıları Gurebâ-yı Müslimîn Hastanesi Külliyesi (1845), Bâlâ Süleyman Ağa Külliyesi (1863) ve Vâlide Külliyesi (1871) ise şehrin sosyal alt yapısının yetersiz olduğu, gelişmemiş bölgeleri için inşa edilmiştir. Cami, sıbyan mektebi, çeşme gibi halkın günlük ihtiyaçlarını karşılayan birimleri bünyesinde bulunduran büyük ölçekli yapılar kent planlamasının ana unsurlarından biri olmuştur. Külliyelerin çevresi zamanla kalabalıklaşmış, bu eserlerin yapıldığı alanlar önemli bir kent hareketliliğine sahne olarak günümüze kadar ulaşan merkezler hâline gelmiştir. Bezmiâlem Valide Sultan'ın inşa ettirdiği Gurebâ-yı Müslimîn Hastanesi Külliyesi (1845) Yenibahçe; Âdile Sultan ve Perestû Kadınefendi’nin yaptırdığı Bâlâ Süleyman Ağa Külliyesi (1863) Silivrikapı; Pertevniyal Vâlide Sultanın inşa ettirdiği Valide Külliyesi (1871) Aksaray semtinin gelişimine büyük katkılarda bulunmuştur.

Gurebâ-y1 Müslimîn Hastanesi Külliyesi (1845) yüzyılın en büyük sağlık yap1larından biri olması açısından önemlidir. Modern sağlık kurumlarının yeni modelini teşkil eden yapının inşası için Yenibahçe Çayırı seçilmiştir. Bu alanın en önemli özelliği şehirden uzak, havadar, yeşil dokunun egemen olduğu hasta tedavisi için oldukça elverişli bir bölge olmasıdır. Söz konusu alan Cumhuriyet'in ilanından sonra da İstanbul'un sağlık alanındaki önemli merkezlerinden biri olma işlevini sürdürmüştür. Ayrıca bu alanda Vakıf Gureba Hastanesi ile birlikte İstanbul Üniversitesi Tıp Fakültesi Hastanesi, Kızılay Kan Merkezi, Özel Çapa Hastanesi gibi sağlık yapıları toplanmıştır.

Gurebâ-yı Müslimîn Hastanesi Külliyesi (1845) dışında halkın ibadet, eğitim ve su gibi temel ihtiyaçlarına cevap veren en önemli külliyelerden bir olan Bâlâ Süleyman Ağa Külliyesi’ni (1863) Sazkâr Kalfa, Adile Sultan ve Perestû Kadın Efendi ihya ve inşa etmişlerdir. Bâlâ Süleyman Ağa Külliyesi (1863) aynı zamanda kent dokusundaki organizasyonu açısından ilginç bir yapıdır. Yapıların arasında kalan yollar hem binalar arasındaki sirkülasyonu sağlamış hem de içinde bulunduğu mahallenin sokak dokusunu oluşturmuştur.

Pertevniyal Vâlide Sultan'nın Aksaray’da Kâtip Camii olarak bilinen eski bir yapının yerine inşa ettirdiği kompleks, bir saray kadının 19. yüzyılda yaptırdığı en 
kapsamlı yapı grubudur. Aksaray Valide Külliyesi (1871) İstanbul'da modern şehircilik çalışmalarının ilk olarak başladığı bir bölgeye konumlandırılmıştır. Bu alan 19. yüzyıla kadar Osmanlı tarihinde görülmeyen bir kentsel planlamaya sahne olmuştur. 1854 'te büyük bir yangın geçiren semtin yeniden düzenlenme işi İtalyan Mühendis Luigi Storari'ye verilmiş ve ilk defa İstanbul şehir planında birbirine paralel sokak düzeni ile birlikte batılı anlamda "meydan" oluşumu sağlanmıştır. Pertevniyal Valide Sultan Külliyesi'nin (1871) cami, türbe ve sebil gibi unsurları Aksaray'daki bu meydanın köşelerine eklemlenmiştir.

Saray kadınlarının inşa faaliyetleri Osmanlı'nın son döneminde her alana yayılııştır. Hanım sultanlar kişisel birikimlerinin yanı sıra devlet desteği ile kurdukları vakıflar eliyle inşa ve tamir ettikleri; dini, eğitim, askeri sivil ve sosyal yapılarla İstanbul şehir dokusunda önemli izler bırakmışlardır. Bu araştırmada belli başlı yapılarıyla bahsettiğimiz saray kadınlarının Osmanlı mimarlığının içinde büyük yapıların banileri olarak oraya çıkmaları onların sadece inşa faaliyetleri ile değil aynı zamanda sosyal alanda da önemli görevleri olduğunu göstermektedir.

Batılılaşma dönemi ile birlikte kadın bânilerin inşa ettirdikleri yapıların türlerinde bir çeşitlenme ortaya çıkmıştır. Cami, mescit, çeşme türbe, imaret ve medrese hemen her dönemde inşa edilen yapılardır. XVIII. yüzyılda kadın bâniliğin ilgi alanında genişleme başlamış ve bu 19. yüzyılda daha da artmıştır. Osmanlı hanım sultanları bu dönemden sonra su yolu, su bendi, sebil, meydan çeşmesi, muvakkithâne, sahilsaray, yalı, köşk, hastane, çamaşırhane, fabrika ve gemi inşa havuzları gibi farklı yapıların inşasını da üstlenmişlerdir. Bânilerin faaliyetlerinin alanlarının genişlemesinden toplumun ve devletin neye ihtiyacı varsa sultanların onu yaptırdıkları sonucu çıkarılabilir.

$\mathrm{Bu}$ araştırmada bahsettiğimiz külliyeler dışında Yahya Efendi Tekkesi (1538), Beykoz Camii, Mihrişah Valide Sultan Camii (1794), Âdile Sultan Türbesi (1849), Valide Mektebi (1850), Bezmiâlem Valide Sultan Camii (1853), Paşalimanı Un Değirmeni (1864), Mihrişah Valide Sultan Meydan Çeşmesi (1806), Hatice Sultan Çeşmesi (1806) ve Bezmiâlem Valide Sultan Çeşmesi (1839) gibi kadın bâniler adına inşa/ tamir edilen önemli yapılar da hanım sultanların 19. yüzyıl bayındırlık faaliyetlerinde yönlendirici olduklarını ve hamilik yaptıkları sonucunu ortaya koymaktadır.

İstanbul'un tarih boyunca ihtiyacı olan en önemli su yapıları saray kadınlarının inşa eylemlerinin büyük bir bölümünü oluşturmuştur. 18. yüzyıldan itibaren hanım sultanlar şehrin su şebekesini geliştirmek, yeni yerleşim yerlerine çeşme ve sebiller yaptırmak amacıyla oldukça maliyetli inşa faaliyetlerine girişmişlerdir. Taksim ve Üsküdar su yollarına önemli müdahalelerde bulunan hanım sultanlar bu yollar üzerine birçok çeşme ve sebil yaptırmıştır. 
19. yüzyılın ikinci yarısında Ortaköy ile Kuruçeşme arası hanım sultanlar için sahilsarayların yoğunlaştığı bir bölge olmuştur. Sultan II. Mahmud'un ilk Çırağan Sarayı'nı (1834-1839) inşa ettirmesinden sonra saray erkânının ilgisi bu bölgeye artmaya başlamış, zaman içerisinde birçok yalı satın alınarak Hazine-i Hassa tarafından pek çok sahilsaray inşa ettirilmiştir. Sultan Abdülaziz (1861-1876) ve II. Abdülhamid (1876-1909) dönemlerinde bu sahilsarayların bir kısmı geçici olarak devlet adamlarına ve hanım sultanlara tahsis edilirken bir kısmı da mülkiyeti ile birlikte verilmiştir. Saray mensuplarının ikametiyle birlikte bölge cazibe merkezi hâline gelmiş, yeni yollar açılmış, karakollar tesis edilmiş ve deniz ulaşımı için yeni iskeleler kurulmuştur.

Osmanlı saray elitinin Boğaziçi kıyılarına yerleşmesi bu bölgelere hizmet gitmesini de sağlamıştır. Kıyı şeridi boyunca birçok sahilsarayın inşa edilmesi ve buna bağlı olarak ortaya çıkan nüfus artışı Boğaziçi semtlerinde su ihtiyacını arttırmıştır. Bunun için Taksim Suyolu'na eklenen ve Boğaziçi'ne uzanan kollar üzerine 19. yüzyılda hanım sultanlar tarafından birçok çeşme yaptırılmıştır. Ayrıca var olan su yolları iyileştirilmiş ve genişletilmiş, ihtiyaç halinde yenileri yaptırılmıştır. Böylece saray mensuplarının burada ikameti ile birlikte su yolları güçlendirilmiş ve bölge halkı bol suya kavuşmuştur.

Osmanlı'nın 19. yüzyıldaki sanayi reformları kapsamında Pertevniyal Valide Sultan tarafından 1864 yılında inşa edilen un değirmeni saray kadınlarının yaptırdığı tek sanayi yapısıdır. Paşalimanı Un Değirmeni Osmanlı İmparatorluğu'nun Batılılaşma sürecinde kent silüetini değiştiren sanayi kuruluşlarından birisidir.

İstanbul'un kent dokusu açısından en büyük değişimi yaşadığ 19. yüzyılda Osmanlı saray kadınlarının adına gerçekleştirilen inşa faaliyetleri önemli bir yer tutmaktadır. Hanedan mensubu kadınların bu değişim sürecince önemli aktörler olarak ortaya çıktığı görülmektedir. Azımsanmayacak kadar çok eserde imzası bulunan sultanlar bu döneme damgasını vurmuştur.

\footnotetext{
Hakem Değerlendirmesi: Dış bağımsız.

Çıkar Çatışması: Yazar çıkar çatışması bildirmemiştir.

Finansal Destek: Yazar bu çalışma için finansal destek almadığını beyan etmiştir.

Peer-review: Externally peer-reviewed.

Conflict of Interest: The author has no conflict of interest to declare.

Grant Support: The author declared that this study has received no financial support.
}

\section{Kaynakça/References}

Alman Mavileri: 1913-1914 I. Dünya Savaşı Öncesi İstanbul Haritaları. 3. Cilt. Haz. İrfan Dağdelen. İstanbul: İstanbul Büyükşehir Belediyesi Başkanlığı Kütüphane ve Müzeler Müdürlüğü Yayınları, 2006.

Ahmed Efendi. Ruznâme. Haz. V. Sema Arıkan. Ankara: Türk Tarih Kurumu Yayınları, 1993. 
Ahmed Lütfi Efendi. Vak'anüvis Ahmed Lütfì Efendi Tarihi. 9. Cilt. Yay. Münir Aktepe. İstanbul: İstanbul Üniversitesi Yayınları, 1984.

Ahmed Lütfi Efendi. Vak'a-nüvis Ahmed Lütfí Efendi Tarihi. 10. Cilt. Haz. Münir Aktepe. Ankara: Türk Tarih Kurumu Yayınları, 1988.

Ahmed Lütfi Efendi. Vak'anüvis Ahmed Lütfi Efendi Tarihi. 6-7-8. Cilt. Haz. Yücel Demirel. İstanbul: Yapı Kredi Kültür Sanat Yayıncılık, 1999.

Ahunbay, Zeynep. “Eyüp’teki Osmanlı Eğitim Yapıları ve Korunmalarıyla İlgili Öneriler”, IV. Tarihi ve Kültürü ve Sanatıyla Eyüpsultan Sempozyumu. İstanbul: Eyüp Belediyesi Yayınlar1 2000, 132-141.

Ak, Mahmut. "Vakıf Kurucusu Bir Hanım: Mihrimah Sultan" Vakıflar Dergisi: Vakıf Medeniyeti Yılı Özel Sayısı (2006): 80-87.

Akçıl Harmankaya N. Çiçek. Mimar Sinan Camilerinde Sembolizm. İstanbul: Kitabevi Yayınları, 2018.

Aksoy, Özgönül. “Osmanlı Devri Sıbyan Mektepleri Üzerine Bir Deneme.” Doktora tezi, İstanbul Teknik Üniversitesi, 1968.

Akkan, Tülay. "Mimar Sinan'in Saraylı Kadınlar İçin Yapmış Olduğu Eserler ve Bu Eserlerin Mimari Özellikleri.”Yüksek Lisans tezi, Mimar Sinan Güzel Sanatlar Üniversitesi, 2009.

Akyıldız, Ali. Haremin Padişahı Valide Sultan Harem'de Hayat ve Teşkilat. İstanbul: Timaş Yayınlar1, 2017.

Amics, Edmondo De. İstanbul (Constantinopoli), Çev. Sevinç Tezcan Yanar. İstanbul: Pegasus Yayınları, 2009.

Ayverdi, Ekrem Hakkı. Fatih Devri Sonlarında İstanbul Mahalleleri Şehrin İskânı ve Nüfusu. Ankara: Vakıf Umum Müdürlüğü Yayınları, 1958.

Ayverdi, Ekrem Hakk1. XIX. Asırda İstanbul Haritası. İstanbul: İstanbul Fethi Derneği Yayınları, 1958.

Bates, Ülkü. "Women as Patron of Architecture in Turkey". Women in Muslim World. Ed. Lois Back and Nikki Keddie. Cambridge: Harvard University Press, 1978, 243-260.

Batur, Afife. "Bezmiâlem Gurebâ-yı Müslimîn Hastahanesi Ek Yapıları Mimar Kemaleddin Bey Tasarımları”, 2010 Vakıf Medeniyeti Ístanbul Yılı ve Vakıflar Haftası Etkinlikleri. Ankara: Vakıflar Genel Müdürlüğü Yayınları, 2011, 118-122.

Bozkurt, Tolga. “Osmanlı Mimarisinde Hanım Sultan Camileri”, Din ve Hayat 48 (2013): 48-51.

Cantay, Gönül. "XIX. Yüzyılda Kurumsallaşma ve Hastahaneler- I”, Fatih Sultan Mehmet İnsan ve Toplum Bilimleri Dergisi 1 (2013): 108-126.

Cantay, Gönül. Osmanlı Külliyelerinin Kuruluşu. Ankara: Atatürk Kültür Merkezi Başkanlığı Yayınları, 2002.

Çaylak 55. 16 Eylül 1292 [28 Eylül 1876], 3.

Çelik, Zeynep. 19.Yüzyılda Osmanlı Başkenti ve Değişen İstanbul. Çev. Selim Deringil. İstanbul: Türkiye İş Bankası Kültür Yayınları, 2016.

Çelik, Zeynep. The Remarking of Istanbul Potrait of an Ottoman City in the Nineteenth Century. London Berkley CA: University of California Press, 1993.

Çıkla Bölükbaşı, Ayşe. “Erken Osmanlı Devleti’nde Kadınların Mimari Alandaki Hamiliği (12991512)", Sanat Tarihi Yıllı̆̆ 19 (2007): 73-90. 
Delibaş, Nurullah. Kitâbelerin Kitabı Fatih. Çev. Mehmet Samsakçı ve Murat Ali Karavelioğlu. İstanbul: Fatih Belediyesi Yayınları, 2016.

Ergin, Osman Nuri. Mecelle-i Umûr-ı Belediyye, 1. Cilt. İstanbul: İstanbul Büyükşehir Belediyesi Yayınları, 1995.

Ergin, Osman Nuri. Mecelle-i Umûr-ı Belediyye, 3. Cilt. İstanbul: İstanbul Büyükşehir Belediyesi Yayınları, 1995.

Erzen, J. Nejat. Mimar Sinan Estetik Bir Analiz. Ankara: Şevki Vanlı Mimarlık Vakfı Yayınları, 1996.

Eyice, Semavi. “Eyüp'de Zal Mahmud Paşa Camii,” V. Tarihi ve Kültürü ve Sanatıyla Eyüpsultan Sетроzуити. İstanbul: Eyüр Belediyesi Yayınları, 2002, 12-21.

Eyice, Semavi. "Fatih Camii ve Külliyesi”, TDV İslâm Ansiklopedisi. 12. Cilt. İstanbul: Türkiye Diyanet Vakfi, 1995, 244-249.

Freely, John. A History of Ottoman Architecture. Boston: Wit Press, 2011.

Göçer, Kenan. "Sosyo- Ekonomik Yönleriyle Bezmiâlem Vâlide Sultan Vakıf Gureba Hastahanesi," Doktora tezi, Marmara Üniversitesi, 2012.

Günpınar, M. Ulvi, Aynur Özcan, Güzin Taştekin ve A. Ruhi Dinçer. XIX. Yüzyıldan XX. Yüzyıla Necib Bey Haritaları'ndan Günümüze Öncesi ve Sonrası, 1. Cilt. İstanbul: Mimar Sinan Vakfı Yayınları,2013.

Gürkan, K. İsmail. Bezmiâlem Valide Sultan Vakıf Gureba Hastanesi Tarihçesi, İstanbul: Özışık Matbaas1, 1967.

Haskan, M. Nermi. Eyüp Tarihi. 1. Cilt. İstanbul: Türkiye Turing Turizm İşletmeciliği Yayınları, 1993.

Hattatoğlu, Muhittin. “İstanbul Silivrikapı'da Topçubaşı Balâ Süleyman Ağa Mimari Manzumesi”, Vakıflar Dergisi 4 (1958): 183-191.

Hovhannesyan, S. Sarkis. Payitaht İstanbul'un Tarihçesi. Çev. Elomon Hançer ve Haz. Ayşen Anadol. İstanbul: Tarih Vakfı Yurt Yayınları, 1996.

Hüseyin Ayvansarayî, Ali Sat' Efendi, Süleymân Besîm Efendi. Hadikatü'l- Cevâm 'i: (İstanbul Camileri ve Diğer Dini-Sivil Mimari Yapılar). Haz. A. Nezih Galitekin. Ankara: İşaret Yayınları, 2001.

İdemen, Nezihe. "1869-1876 Yılları Arasında Yayınlanan Mizah Gazetelerinde İstanbul Hayatı." Yüksek Lisans tezi, İstanbul Üniversitesi, 1994.

İlhanl1, Emine. "Sineperver Ayşe Vâlide Sultan, Nakşidil Vâlide Sultan ve Perstû Valide Sultan Vakıfları.” Yüksek Lisans tezi, Fatih Sultan Mehmet Vakıf Üniversitesi, 2018.

Kalafat, Murat. "Üsküdar: Harem Kadınlarının Prestij Sahası”. Art- Sanat 14 (2020): 185-209.

Kuban, Doğan. Osmanlı Mimarisi. İstanbul: Yem Yayınları, 2007.

Mülayim, Selçuk. “Beylerbeyi Camii ve Külliyesi”, TDV İslâm Ansiklopedisi. 6. Cilt. İstanbul: Türkiye Diyanet Vakfi, 1992, 75-77.

Önkal, Hakkı. "Eyüp Mihrişah ve Şah Sultan Türbelerinin Kitabeleri Işı̆̆ında Mihrişah Kadın Meseleleri”, V. Tarihi, Sanatı ve Kültürüyle Eyüpsultan Sempozyumu. İstanbul: Eyüp Belediyesi Yayınlar1, 2002, 122-125.

Özcan, Tahsin. "Vakıf Şehidi Bir Saraylı: Gülfem Hatun”, Vakıflar Dergisi: Vakıf Medeniyeti Yılı Özel Saylsı (2006): 97-98. 
Parlak, Sevgi. "Şah Sultan Külliyesi.” TDV İslâm Ansiklopedisi. 30. Cilt. İstanbul: Türkiye Diyanet Vakfi, 2010, 258-260.

Pervititch, Jacques. Sigorta Haritalarında İstanbul. İstanbul: Tarih Vakfi Yayınları, [t.y.].

Pierce, Leslie P. Harem-i Hümayûn Osmanlı Imparatorluğunda Hükümdarlık ve Kadınlar. Çev. Ayşe Berktay. İstanbul: Tarih Vakfı Yayınları, 1996.

Sarıcaoğlu, Fikret. "Nakşidil Valide Sultan”, Türklük Araştırmaları Dergisi 9 (2001): 97-109.

Sarıcaoğlu, Fikret. "Nakşidil Sultan.” TDV İslâm Ansiklopedisi. 32. Cilt. İstanbul: Türkiye Diyanet Vakfi, 2006, 343-344.

Şentürk, M. Hüdaî. “Bezmiâlem Vâlide Sultan'ın Hayatı ve Hayır Eserleri”. İstanbul Araştırmaları 6 (1998): 7-69.

Tanman, M. Baha. "Bâlâ Külliyesi." TDV İslâm Ansiklopedisi. 4. Cilt. İstanbul: Türkiye Diyanet Vakfi, 1991, 554-556.

Tanman, M. Baha. "İstanbul Tekkelerinin Mimari ve Süsleme Özellikleri Tipoloji Denemeleri." Doktora tezi, İstanbul Üniversitesi, 1990.

The Levand Herald 40. 5 April 1872, 158-159.

Thys-Şenocak, Lucienne. Hadice Turan Sultan Osmanlı İmparatorluğunda Kadın Bâniler. Çev. Ayla Ortaç. İstanbul: Kitap Yayınevi, 2009.

Uşar, B. Bahar. "The Aksaray Pertevniyal Valide Sultan Complex: Reflections on the Patronage of a Nineteenth Century Valide Sultan.” Yüksek Lisans tezi, Koç Üniversitesi, 2016.

White, Charles. Tree Years in Constantinople; or Domestic Manners the Turks in 1844. 3. Volume. London: Henry Colburn Publiser, 1846.

Yavaş, Doğan. "Pertevniyal Valide Sultan Külliyesi”. TDV İslâm Ansiklopedisi. 34. Cilt. İstanbul: Türkiye Diyanet Vakfi, 2007, 241-242.

Yavuztürk, Ş. Pınar. "Silivrikapı Semti”. İstanbul'un Kitabı Fatih. 1. Cilt. İstanbul: Fatih Belediyesi Yayınlar1, 2013, 286-300.

Yıldırım, Nuran. Gureba Hastanesinden Bezmîalem Vakıf Üniversitesi'ne (From Charity Hospital to the Bezmialem Foundation University). İstanbul: Bezmiâlem Vakıf Üniversitesi Yayınları, 2013.

Erişim 14 Mayıs 2019. http:/www.web.fomgrup.com/TR/50/projedetay/

Erişim 9 Aralık 2021. https://bezmialem.edu.tr/tr/Sayfalar/idari/uluslararasi-iliskiler-ofisi/ fotograflarla-bezmialem.aspx

Erişim 14 Ekim 2018. http://www.eskiistanbul.net/5784/aksaray 